OPEN ACCESS

Edited by:

Maximo Vento,

Hospital Universitari i Politècnic La Fe,

Spain

Reviewed by:

Robert Galinsky,

Ritchie Centre, Australia

Gunnar Naulaers,

KU Leuven, Belgium

*Correspondence:

Po-Yin Cheung

poyin@ualberta.ca

Specialty section:

This article was submitted to

Neonatology,

a section of the journal

Frontiers in Pediatrics

Received: 06 July 2018 Accepted: 08 November 2018 Published: 10 December 2018

Citation:

Joynt $C$ and Cheung P-Y (2018)

Cardiovascular Supportive Therapies

for Neonates With Asphyxia - A

Literature Review of Pre-clinical and

Clinical Studies. Front. Pediatr. 6:363.

doi: 10.3389/fped.2018.00363

\section{Cardiovascular Supportive Therapies for Neonates With Asphyxia - A Literature Review of Pre-clinical and Clinical Studies}

\author{
Chloe Joynt ${ }^{1}$ and Po-Yin Cheung ${ }^{1,2,3 *}$ \\ ${ }^{1}$ Department of Pediatrics, University of Alberta, Edmonton, $A B$, Canada, ${ }^{2}$ Department of Pharmacology, University of \\ Alberta, Edmonton, AB, Canada, ${ }^{3}$ Centre for the Study of Asphyxia and Resuscitation, Edmonton, AB, Canada
}

Asphyxiated neonates often have hypotension, shock, and poor tissue perfusion. Various "inotropic" medications are used to provide cardiovascular support to improve the blood pressure and to treat shock. However, there is incomplete literature on the examination of hemodynamic effects of these medications in asphyxiated neonates, especially in the realm of clinical studies (mostly in late preterm or term populations). Although the extrapolation of findings from animal studies and other clinical populations such as children and adults require caution, it seems appropriate that findings from carefully conducted pre-clinical studies are important in answering some of the fundamental knowledge gaps. Based on a literature search, this review discusses the current available information, from both clinical studies and animal models of neonatal asphyxia, on common medications used to provide hemodynamic support including dopamine, dobutamine, epinephrine, milrinone, norepinephrine, vasopressin, levosimendan, and hydrocortisone.

Keywords: newborn, asphyxia, inotropes, catecholamines, hemodynamics

\section{INTRODUCTION}

Asphyxia is a clinico-pathological condition that is caused by a hypoxic-ischemic insult resulting in dysfunction of one or more organ systems in over $80 \%$ of asphyxiated neonates $(1,2)$. Asphyxiated neonates may have a decreased cardiac output (CO) state with ventricular myocardial dysfunction, decreased left ventricular preload secondary to pulmonary hypertension and/or decreased ability to regulate vessel tone (vasoplegia). The critically ill neonate may have hypoxia-ischemia of vital organs including the brain, intestine, kidney and lung (2-4). Therefore, asphyxiated neonates have significant mortality and long-term morbidity including physical and mental disability $(2,5,6)$.

Cardiovascular support is often provided using a myriad of medications to treat the complex and heterogeneous etiologies of hemodynamic compromise or instability in asphyxiated neonates. Most commonly, "antihypotensive" treatments are administered when the infant develops low blood pressure (BP) or signs of low $\mathrm{CO}$. However, the challenge for clinicians caring for asphyxiated neonates is to understand the pathophysiology of hemodynamic disturbances and then provide an individualized therapy to the patient. It is important to be cognizant of a hemodynamic state that evolves through feto-neonatal transition in the course of an asphyxiating disease and recovery, as well as the interaction between hemodynamics and concurrent treatments including respiratory state and positive pressure ventilation, and therapeutic hypothermia (TH). 
Many clinicians assume that BP and systemic perfusion are proportionally related. However, this assumption requires validation as $\mathrm{BP}$, vascular resistance and $\mathrm{CO}$ can be independent yet interactive factors for systemic and regional perfusion. Evaluation of cardiac performance and regional tissue oxygenation provide important information to understand systemic and regional hemodynamic state. Evaluation tools include echocardiographic examination, near-infrared spectroscopy, in addition to conventional markers such as acid-base balance, plasma lactate and urine output. Functional echocardiography may also provide point-of-care information regarding the ventricular function, shunting and volume status (7). The clinical application of near infrared spectroscopy has gained popularity for the real-time measurement of regional tissue perfusion and oxygenation trends in recent years (8).

While many of the neonatal studies of hypotension and treatments highlight that practices are variable across countries and heterogeneity of patients, the vast majority focus on the premature population but not asphyxiated neonates $(9,10)$. The study by Burns et al. reported $41 \%$ of those babies receiving cardiovascular supportive drugs were born at term with a variety of pathological conditions including necrotising enterocolitis, pulmonary hypertension (PHT), birth asphyxia, surgery, sepsis, and cardiac diseases (10). Although the use of cardiovascular supportive drugs was associated with increased mortality, this finding was not observed in the TH group (10)

In this review, we searched the literature of clinical (Table 1) and pre-clinical animal (Table 2) studies regarding the hemodynamic effects of dopamine, dobutamine, epinephrine, milrinone, norepinephrine, vasopressin, levosimendan, and hydrocortisone administration in newborn or infantile subjects with asphyxia, hypoxia-reoxygenation, or cardiac surgery. We will discuss the hemodynamic effects of various cardiovascular supportive therapies in asphyxiated neonates following resuscitation. Other therapies including methylene blue (an inhibitor of nitric oxide-cGMP pathway), calcium (in hypocalcemic conditions), naloxone (an antagonist of opioids), and triiodothyronine (an inotropic hormone) will not be discussed because the clinical experience in neonatal asphyxia or hypoxia-reoxygenation is anecdotal.

\section{VARIABLES IN HYPOTENSION OR LOW PERFUSION STATES IN ASPHYXIATED NEONATES}

In comparison with the heart of older children, the basal contractile state is higher and compliance is lower in the neonatal heart,(52) which also has a higher resting ventricular output per kilogram of body weight than that of adults (53). In addition, the neonatal cardiomyocytes' excitation-contraction coupling and transverse tubular framework is not yet fully developed and not overly resilient to a hypoxic insult (54). Thus, in the neonatal heart, reserves for contractility, ventricular output and energy are reduced with compromised capability in response to stressors.

In addition to the transitional and neonatal physiology including fetal shunts, asphyxiated neonates have altered cardiac and vascular functions that can result in hypotension ${ }^{1}$ and/or low $\mathrm{CO}^{1}$ or perfusion states. Furthermore, iatrogenic effects of concurrent treatments, such as $\mathrm{TH}$ and rewarming as well as ventilation can also contribute to the disruption of the hemodynamic homeostasis. Upon the resuscitation of asphyxiated neonates, reactive oxygen species are produced during reoxygenation and reperfusion. This can lead to adverse effects including plasma membrane disruption, mitochondrial dysfunction and apoptosis (55-59).

In asphyxiated neonates, attenuated parasympathetic and increased sympathetic nervous activities play a significant role in the hemodynamic changes with initial tachycardia and increased (or normalized) BP during asphyxia and after the resuscitation $(60,61)$. Following the initial recovery, cardiac dysfunction develops including reduced myocardial contractility and passive dilation, which often occur in conjunction with systemic hypotension and PHT $(3,62,63)$. PHT of asphyxiated neonates has a multitude of effects on the compromised myocardium including decreased systemic blood flow, increased right ventricular afterload and stress, increased cardiac transmural pressure with decreased perfusion in the subendocardial layer, and aggravated systemic hypoxemia with right-to-left shunting across a patent ductus arteriosus and foraman ovale (64-66). With poor perfusion or $\mathrm{CO}$, acidosis can develop, which can further aggravate PHT leading to increasing cardiac afterload and additive stress to a dysfunctional ventricle $(63,67)$.

Asphyxiated neonates may have vasomotor dysregulation even to the point of vasomotor paresis (vasoplegia) which may impair autoregulation or affect the redistribution of regional blood flow and perfusion $(68,69)$. The relationship between $\mathrm{BP}, \mathrm{CO}$, and organ perfusion may be altered with the interplay between BP-dependency and flow-dependency in the regulation of tissue perfusion and oxygenation as has been shown in the brain and gut (70-76).

When a decision to treat is made, it is imperative to consider the history of the baby and their antenatal and postnatal course, the dynamic state of the cardiovascular compromise and the contribution of cardiac, pulmonary, and vascular dynamics that may vary for each neonate. Clinical parameters should be put into context with the information available be it clinical, laboratory, echocardiographic or regional oxygenation as indicated by near infrared spectroscopy (77). In addition, the concomitant effects of treatments for asphyxia including $\mathrm{TH}$, rewarming, sedation, ventilation, anticonvulsants, to name a few, should be considered in treatment decisions as to whether to initiate cardiovascular supportive treatment and in antihypotensive agent.

During $\mathrm{TH}$, the heart rate falls and systemic vascular resistance may increase (54). Studies have shown that CO in cooled neonates is approximately $2 / 3$ of their normothermic baseline (78). Although myocardial contractility may be enhanced during $\mathrm{TH}$ due to an increased sensitivity to calcium,

\footnotetext{
${ }^{1}$ We refer "hypotension" and "low cardiac output" to clinical condition(s) that the asphyxiated neonate has low blood pressure (leading to e.g., cerebral or renal perfusion deficits, right-to-left shunting across patent ductus arteriosus) and decreased systemic perfusion deficits (e.g., tissue hypoxia), and therefore require respective therapies.
} 
TABLE 1 | Relevant clinical studies on the hemodynamic effects of cardiovascular medications in term or near-term neonates with asphyxia and other conditions.

\begin{tabular}{|c|c|c|c|c|}
\hline Publication & Clinical population & Medication studied & Significant findings & Study design \\
\hline DiSessa et al. (11) & $\begin{array}{l}14 \text { severely asphyxiated } \\
\text { neonates }\end{array}$ & $\begin{array}{l}\text { Dopamine } 2.5 \mathrm{mcg} / \mathrm{kg} / \mathrm{min} \text { vs. } \\
\text { placebo }\end{array}$ & $\begin{array}{l}\text { Increased cardiac performance } \\
\text { (echocardiography) and systolic blood } \\
\text { pressure }\end{array}$ & $\begin{array}{l}\text { Double-blind, randomized } \\
\text { trial }\end{array}$ \\
\hline $\begin{array}{l}\text { Walther FJ et al. } \\
\text { (12) }\end{array}$ & $\begin{array}{l}6 \text { neonates with severe } \\
\text { asphyxia }\end{array}$ & Dopamine $4-10 \mathrm{mcg} / \mathrm{kg} / \mathrm{min}$ & $\begin{array}{l}\text { Increased blood pressure and heart rate; } \\
\text { improved left ventricular myocardial } \\
\text { dysfunction (echocardiography) }\end{array}$ & Observational study \\
\hline Chang et al. (14) & $\begin{array}{l}10 \text { neonates after cardiac } \\
\text { surgery }\end{array}$ & $\begin{array}{l}\text { Milrinone } 0.5 \mathrm{mcg} / \mathrm{kg} / \mathrm{min} \text { after } \\
\text { loading dose of } 50 \mathrm{mcg} / \mathrm{kg}\end{array}$ & $\begin{array}{l}\text { Improved cardiac index with reduced } \\
\text { systemic and pulmonary arterial pressures } \\
\text { and respective vascular resistances }\end{array}$ & Prospective cohort study \\
\hline Hoffman et al. (15) & $\begin{array}{l}238 \text { infants and children } \\
\text { after cardiac surgery }\end{array}$ & $\begin{array}{l}\text { Milrinone } 0.25,0.5 \text {, and } 0.75 \\
\mathrm{mcg} / \mathrm{kg} / \mathrm{min} \text { vs. placebo }\end{array}$ & $\begin{array}{l}\text { High-dose milrinone reduced the risk of } \\
\text { low cardiac output syndrome }\end{array}$ & $\begin{array}{l}\text { Double-blind, randomized } \\
\text { trial }\end{array}$ \\
\hline Lechner et al. (18) & $\begin{array}{l}17 \text { neonates with } \\
\text { vasopressor-resistant } \\
\text { hypotension after cardiac } \\
\text { surgery }\end{array}$ & $\begin{array}{l}\text { Vasopressin } 0.0001-0.0003 \\
(0.00005-0.001) \mathrm{U} / \mathrm{kg} / \mathrm{min}\end{array}$ & $\begin{array}{l}\text { Increased blood pressure and decreased } \\
\text { dosage of traditional vasopressors }\end{array}$ & Prospective cohort study \\
\hline Tourneux et al. (19) & $\begin{array}{l}22 \text { neonates with persistent } \\
\text { septic shock }\end{array}$ & $\begin{array}{l}\text { Norepinephrine } 0.5 \pm 0.4 \\
\mathrm{mcg} / \mathrm{kg} / \mathrm{min}\end{array}$ & $\begin{array}{l}\text { Increased arterial blood pressure and urine } \\
\text { output with decreased lactate }\end{array}$ & $\begin{array}{l}\text { Prospective observational } \\
\text { study }\end{array}$ \\
\hline Tourneuxet al. (20) & $\begin{array}{l}18 \text { neonates with PPHN and } \\
\text { cardiac dysfunction }\end{array}$ & $\begin{array}{l}\text { Norepinephrine } 0.5 \pm 0.4 \\
\mathrm{mcg} / \mathrm{kg} / \mathrm{min}\end{array}$ & $\begin{array}{l}\text { Increased systemic blood pressure, } \\
\text { cardiac output and pulmonary artery blood } \\
\text { flow (echocardiography); decreased } \\
\text { pulmonary/systemic pressure ratio and } \\
\text { oxygen need }\end{array}$ & $\begin{array}{l}\text { Prospective observational } \\
\text { study }\end{array}$ \\
\hline Alten et al. (24) & $\begin{array}{l}37 \text { neonates after cardiac } \\
\text { surgery }\end{array}$ & $\begin{array}{l}\text { Early post bypass Vasopressin } \\
0.0003 \mathrm{U} / \mathrm{kg} / \mathrm{min}(0.0008-0.001) \\
\text { vs. no vasopressin }\end{array}$ & $\begin{array}{l}\text { Lower inotropic score and fluid } \\
\text { resuscitation }\end{array}$ & $\begin{array}{l}\text { Retrospective cohort } \\
\text { observational study }\end{array}$ \\
\hline $\begin{array}{l}\text { McNamara et al. } \\
\text { (25) }\end{array}$ & $\begin{array}{l}11 \text { neonates with severe } \\
\text { persistent pulmonary } \\
\text { hypertension of newborn }\end{array}$ & $\begin{array}{l}\text { Milrinone } 0.33-0.99 \mathrm{mcg} / \mathrm{kg} / \mathrm{min} \\
\text { after loading dose of } 50 \mathrm{mcg} / \mathrm{kg}\end{array}$ & $\begin{array}{l}\text { Improved cardiac output; reduced } \\
\text { pulmonary artery pressure; reduced } \\
\text { oxygenation index and inhaled nitric oxide } \\
\text { dose }\end{array}$ & Observational study \\
\hline $\begin{array}{l}\text { Mohamed et al. } \\
\text { (26) }\end{array}$ & $\begin{array}{l}10 \text { neonates with severe } \\
\text { persistent pulmonary } \\
\text { hypertension of newborn }\end{array}$ & $\begin{array}{l}\text { Vasopressin } 0.0002 \pm 0.0002 \\
\mathrm{U} / \mathrm{kg} / \mathrm{min}\end{array}$ & $\begin{array}{l}\text { Increased blood pressure and urine } \\
\text { output; improved oxygenation index }\end{array}$ & $\begin{array}{l}\text { Retrospective observational } \\
\text { study }\end{array}$ \\
\hline $\begin{array}{l}\text { Oualha M et al. } \\
\text { (27) }\end{array}$ & $\begin{array}{l}39 \text { children after cardiac } \\
\text { surgery }\end{array}$ & $\begin{array}{l}\text { Epinephrine } 0.01-0.23 \\
\mathrm{mcg} / \mathrm{kg} / \mathrm{min} \text { with milrinone }\end{array}$ & $\begin{array}{l}\text { Increased blood pressure, heart rate, } \\
\text { plasma glucose and lactate }\end{array}$ & $\begin{array}{l}\text { Prospective observational } \\
\text { study }\end{array}$ \\
\hline Bianchi et al. (28) & $\begin{array}{l}17 \text { neonates prior to cardiac } \\
\text { surgery }\end{array}$ & Milrinone $0.75 \mathrm{mcg} / \mathrm{kg} / \mathrm{min}$ & $\begin{array}{l}\text { Increased cardiac output, superior } \\
\text { mesenteric and cerebral mean velocities }\end{array}$ & $\begin{array}{l}\text { Prospective observational } \\
\text { study }\end{array}$ \\
\hline James et al. (29) & $\begin{array}{l}17 \text { neonates with severe } \\
\text { persistent pulmonary } \\
\text { hypertension of newborn }\end{array}$ & Milrinone $0.5-0.7 \mathrm{mcg} / \mathrm{kg} / \mathrm{min}$ & $\begin{array}{l}\text { Increased cardiac output; reduced inhaled } \\
\text { nitric oxide dose and oxygen requirement }\end{array}$ & $\begin{array}{l}\text { Retrospective observational } \\
\text { study }\end{array}$ \\
\hline $\begin{array}{l}\text { Giaccone et al. } \\
\text { (30) }\end{array}$ & $\begin{array}{l}6 \text { neonates with severe } \\
\text { persistent pulmonary }\end{array}$ & $\begin{array}{l}\text { Milrinone } 0.2 \text { and } 0.5 \\
\mathrm{mcg} / \mathrm{kg} / \mathrm{min} \text { preceded by } 20 \text { or }\end{array}$ & $\begin{array}{l}\text { Variable response in oxygenation index } \\
\text { which improved with time }\end{array}$ & $\begin{array}{l}\text { Multi-center randomized } \\
\text { open label pilot study }\end{array}$ \\
\hline
\end{tabular}


TABLE 2 | Relevant intact animal studies on the hemodynamic effects of cardiovascular medications in neonatal asphyxia.

\begin{tabular}{|c|c|c|c|c|}
\hline Publication & $\begin{array}{l}\text { Cardiovascular } \\
\text { medication(s) }\end{array}$ & Research model and design & Significant findings & Remarks \\
\hline Walker et al. (31) & $\begin{array}{l}\text { Vasopressin } 0.004 \mathrm{U} / \mathrm{kg} / \mathrm{min} \\
\text { iv }\end{array}$ & $\begin{array}{l}\text { Sprague-Dawley adult rats; } \\
\text { Conscious, unrestrained; } \\
\text { Normoxia and hypoxia }\end{array}$ & $\begin{array}{l}\text { Increased SAP; decreased PAP } \\
\text { (hypoxia>normoxia), CO and HR }\end{array}$ & \\
\hline Caspi et al. (32) & $\begin{array}{l}\text { Epinephrine } 0.5 \text { and } 2.0 \\
\mathrm{mcg} / \mathrm{kg} / \mathrm{min}\end{array}$ & $\begin{array}{l}\text { Newborn piglets; Acutely } \\
\text { instrumented; Normoxia }\end{array}$ & $\begin{array}{l}\text { Increased end-systolic elastance in } \\
\text { high-dose followed by a decrease after } 2 \mathrm{~h} \\
\text { infusion, along with an increase in left } \\
\text { ventricular volume elasricity }\end{array}$ & $\begin{array}{l}\text { Associated with } \\
\text { sarcolemmal rupture and } \\
\text { mitochondrial calcium } \\
\text { granule deposition }\end{array}$ \\
\hline $\begin{array}{l}\text { Barrington KJ } \\
\text { et al. (33) }\end{array}$ & $\begin{array}{l}\text { Dopamine 2-16 } \\
\mathrm{mcg} / \mathrm{kg} / \mathrm{min} \text { vs. Epinephrine } \\
0.2-1.6 \mathrm{mcg} / \mathrm{kg} / \mathrm{min}\end{array}$ & $\begin{array}{l}\text { Newborn piglets; Acutely } \\
\text { instrumented; Normoxia and } \\
\text { hypoxia; Prospective, } \\
\text { randomized, blind, cross-over } \\
\text { study }\end{array}$ & $\begin{array}{l}\text { Both drugs increased CO. Epinephrine in } \\
\text { normoxia: increased SAP with reduced } \\
\text { PAP/SAP ratio. Epinephrine with hypoxia: } \\
\text { increased SAP, reduced PAP, with reduced } \\
\text { PAP/SAP ratio }\end{array}$ & \\
\hline $\begin{array}{l}\text { Ferrara JJ et al. } \\
\text { (34) }\end{array}$ & $\begin{array}{l}\text { Dopamine } 5-15 \\
\mathrm{mcg} / \mathrm{kg} / \mathrm{min} \text { vs. Dobutamine } \\
5-15 \mathrm{mcg} / \mathrm{kg} / \mathrm{min}\end{array}$ & $\begin{array}{l}\text { Newborn piglets; term and } \\
\text { preterm ( } 90 \% \text { gestation); Acutely } \\
\text { instrumented; Normoxia }\end{array}$ & $\begin{array}{l}\text { Both drugs increased SAP at } 15 \\
\text { ug/kg/min in term animals; Dobutamine } \\
\text { increased heart and brain blood flow but } \\
\text { decreased small intestinal blood flow. } \\
\text { Dopamine increased heart and small } \\
\text { intestinal blood flows }\end{array}$ & \\
\hline Cheung et al. (35) & $\begin{array}{l}\text { Dobutamine } 5-50 \\
\mathrm{mcg} / \mathrm{kg} / \mathrm{min} \times 20 \mathrm{~min} \text { and } \\
10 \mathrm{mcg} / \mathrm{kg} / \mathrm{min} \times 1 \mathrm{~h}\end{array}$ & $\begin{array}{l}\text { Newborn piglets; Chronically } \\
\text { instrumented; Normoxia; } \\
\text { Prospective, randomized (dose) } \\
\text { study }\end{array}$ & $\begin{array}{l}\text { Dose-dependent increases in CO; no } \\
\text { effect on mesenteric and renal blood } \\
\text { flows; increased PAP/SAP ratio; prolonged } \\
\text { infusion at } 10 \mathrm{ug} / \mathrm{kg} / \mathrm{min} \text { increased stroke } \\
\text { volume }\end{array}$ & \\
\hline Penny et al. (36) & $\begin{array}{l}\text { Dobutamine } 1-40 \\
\mathrm{mcg} / \mathrm{kg} / \mathrm{min}\end{array}$ & $\begin{array}{l}\text { Newborn lambs; Acutely } \\
\text { instrumented; Normoxia }\end{array}$ & $\begin{array}{l}\text { Increased systemic oxygen delivery and } \\
\text { consumption }\end{array}$ & $\begin{array}{l}\text { Multiple adrenoceptors } \\
\text { activation }\end{array}$ \\
\hline Cheung et al. (37) & $\begin{array}{l}\text { Dopamine 2-32 } \\
\mathrm{mcg} / \mathrm{kg} / \mathrm{min} \text { vs. Epinephrine } \\
0.2-3.2 \mathrm{mcg} / \mathrm{kg} / \mathrm{min} \times 1 \mathrm{~h}\end{array}$ & $\begin{array}{l}\text { Newborn piglets; Acutely } \\
\text { instrumented; Hypoxia; } \\
\text { Prospective, randomized (dose) } \\
\text { study }\end{array}$ & $\begin{array}{l}\text { Epinephrine increased CO Dopamine } \\
\text { increased PAP/SAP ratio, portal venous } \\
\text { blood flow and oxygen delivery }\end{array}$ & \\
\hline Obaid et al. (40) & $\begin{array}{l}\text { Epinephrine } 0.3-1.5 \\
\mathrm{mcg} / \mathrm{kg} / \mathrm{min} v \mathrm{vs} \text {. Dopamine } \\
10-25 \mathrm{mcg} / \mathrm{kg} / \mathrm{min} \times 2 \mathrm{~h}\end{array}$ & $\begin{array}{l}\text { Newborn piglets; Acutely } \\
\text { instrumented; } \\
\text { Hypoxia-reoxygenation; } \\
\text { Prospective, randomized, blind } \\
\text { study }\end{array}$ & $\begin{array}{l}\text { Epinephrine increased CO and SAP with } \\
\text { reduced PAP/SAP ratio. Modest effects } \\
\text { with dopamine. Both regimens similarly } \\
\text { increased regional (carotid and } \\
\text { mesenteric, but not renal) blood flows }\end{array}$ & $\begin{array}{l}\text { SAP-targeted study } \\
\text { protocol }\end{array}$ \\
\hline Joynt et al. (41) & $\begin{array}{l}\text { Milrinone } 0.25-0.75 \\
\mathrm{mcg} / \mathrm{kg} / \mathrm{min} \times 2 \mathrm{~h}\end{array}$ & $\begin{array}{l}\text { Newborn piglets; Acutely } \\
\text { instrumented; } \\
\text { Hypoxia-reoxygenation; } \\
\text { Prospective, randomized, blind } \\
\text { study }\end{array}$ & $\begin{array}{l}\text { Dose-response effect of milrinone in CO; } \\
\text { no effect on SAP and PAP. High-dose } \\
\text { milrinone increased carotid and mesenteric } \\
\text { blood flow and oxygen delivery. }\end{array}$ & $\begin{array}{l}\text { Fluid bolus prior to infusion; } \\
\text { milrinone prevented } \\
\text { aggravated pulmonary } \\
\text { hypertension }\end{array}$ \\
\hline Joynt et al. (42) & $\begin{array}{l}\text { Dobutamine } 20 \mathrm{mcg} / \mathrm{kg} / \mathrm{min} \\
\text { vs. Epinephrine } 0.5 \\
\mathrm{mcg} / \mathrm{kg} / \mathrm{min} \text { vs. Milrinone } \\
0.75 \mathrm{mcg} / \mathrm{kg} / \mathrm{min} \times 2 \mathrm{~h}\end{array}$ & $\begin{array}{l}\text { Newborn piglets; Acutely } \\
\text { instrumented; } \\
\text { Hypoxia-reoxygenation; } \\
\text { Prospective, randomized, blind } \\
\text { study }\end{array}$ & $\begin{array}{l}\text { All regimens similarly increased cardiac } \\
\text { output, stroke volume, carotid and } \\
\text { mesenteric but not renal blood flows; } \\
\text { Dobutamine and epinephrine increased } \\
\text { SAP; Milrinone decreased renal vascular } \\
\text { resistance }\end{array}$ & $\begin{array}{l}\text { No aggravation of } \\
\text { pulmonary hypertension }\end{array}$ \\
\hline Ichikawa et al. (43) & Milrinone $1,10 \mathrm{mg} / \mathrm{kg} \mathrm{ip}$ & $\begin{array}{l}\text { Sprague-Dawley newborn rats; } \\
\text { Conscious, unrestrained; } \\
\text { Normoxia }\end{array}$ & Milrinone dilated ductus arteriosus & \\
\hline
\end{tabular}


TABLE 2 | Continued

\begin{tabular}{|c|c|c|c|c|}
\hline Publication & $\begin{array}{l}\text { Cardiovascular } \\
\text { medication(s) }\end{array}$ & Research model and design & Significant findings & Remarks \\
\hline Esch et al. (44) & $\begin{array}{l}\text { Levosimendan } 0.1,0.2 \\
\mathrm{mcg} / \mathrm{kg} / \mathrm{min} \times 2 \mathrm{~h}\end{array}$ & $\begin{array}{l}\text { Newborn piglets; Acutely } \\
\text { instrumented; } \\
\text { Hypoxia-reoxygenation }\end{array}$ & $\begin{array}{l}\text { Both doses increased } \mathrm{CO}, \mathrm{HR} \text { and } \\
\text { decreased systemic vascular resistance; } \\
\text { low-dose increased PAP; no effects on } \\
\text { regional blood flows }\end{array}$ & \\
\hline Cheung et al. (45) & $\begin{array}{l}\text { Vasopressin 0.005-0.02 } \\
\mathrm{U} / \mathrm{kg} / \mathrm{h} \times 2 \mathrm{~h}\end{array}$ & $\begin{array}{l}\text { Newborn piglets; Acutely } \\
\text { instrumented; } \\
\text { Hypoxia-reoxygenation }\end{array}$ & $\begin{array}{l}\text { Dose-dependently increased SAP with no } \\
\text { effects on CO and regional blood flows }\end{array}$ & $\begin{array}{l}\text { Showed a baro-specific } \\
\text { action }\end{array}$ \\
\hline Pelletier et al. (46) & $\begin{array}{l}\text { Vasopressin } 0.01 \mathrm{U} / \mathrm{kg} / \mathrm{h} \times \\
3.5 \mathrm{~h} \text { vs. Dobutamine } 20 \\
\mathrm{mcg} / \mathrm{kg} / \mathrm{min} \times 2 \mathrm{~h}\end{array}$ & $\begin{array}{l}\text { Newborn piglets; Acutely } \\
\text { instrumented; } \\
\text { Hypoxia-reoxygenation; } \\
\text { Prospective, randomized, blind } \\
\text { study }\end{array}$ & $\begin{array}{l}\text { Both regimens increased } \mathrm{CO} \text { and } \\
\text { mesenteric blood flow }\end{array}$ & $\begin{array}{l}\text { Early administration of } \\
\text { vasopressin prior to severe } \\
\text { cardiogenic shock during } \\
\text { recovery }\end{array}$ \\
\hline Drury et al. (47) & $\begin{array}{l}\text { Dopamine } 4-40 \\
\mathrm{mcg} / \mathrm{kg} / \mathrm{min} \text { vs. saline }\end{array}$ & $\begin{array}{l}\text { Fetal sheep; Near-term ( } 85 \% \\
\text { gestation); Chronically } \\
\text { instrumented; Asphyxia by } \\
\text { umbilical cord compression; } \\
\text { Prospective, randomized, study }\end{array}$ & $\begin{array}{l}\text { Dopamine infusion was associated with a } \\
\text { marked but transient increase in SAP } \\
\text { followed by terminal hypotension. No } \\
\text { effect in carotid blood flow, }\end{array}$ & $\begin{array}{l}\text { SAP-targeted study } \\
\text { protocol; Fetal asphyxia } \\
\text { model. }\end{array}$ \\
\hline $\begin{array}{l}\text { Manouchehri et al. } \\
\text { (48) }\end{array}$ & $\begin{array}{l}\text { Dopamine } 10 \mathrm{mcg} / \mathrm{kg} / \mathrm{min} \\
+ \text { epinephrine } 0.2 \\
\mathrm{mcg} / \mathrm{kg} / \mathrm{min} \text { vs. Dopamine } \\
20 \mathrm{mcg} / \mathrm{kg} / \mathrm{min} \times 2 \mathrm{~h}\end{array}$ & $\begin{array}{l}\text { Newborn piglets; Acutely } \\
\text { instrumented; } \\
\text { Hypoxia-reoxygenation; } \\
\text { Prospective, randomized, blind } \\
\text { study }\end{array}$ & $\begin{array}{l}\text { Both regimens similarly increased CO, } \\
\text { SAP, carotid and mesenteric blood flow, } \\
\text { but not PAP. Dopamine + epinephrine } \\
\text { decreased PAP/SAP ratio. High-dose } \\
\text { dopamine decreased mesenteric vascular } \\
\text { resistance }\end{array}$ & $\begin{array}{l}\text { Study of combined } \\
\text { catecholamines vs. } \\
\text { monotherapy }\end{array}$ \\
\hline Eiby et al. (49) & $\begin{array}{l}\text { Dopamine 10, } 20 \text { ug/ } \mathrm{kg} / \mathrm{min} \\
\text { vs. dobutamine 10, } 20 \\
\mathrm{mcg} / \mathrm{kg} / \mathrm{min}\end{array}$ & $\begin{array}{l}\text { Newborn piglets; term and } \\
\text { preterm ( } 90 \% \text { gestation); Acutely } \\
\text { instrumented; Normoxia }\end{array}$ & $\begin{array}{l}\text { Both increased SAP and HR but not CO } \\
\text { nor cerebral blood flow }\end{array}$ & $\begin{array}{l}\text { Less responses in preterm } \\
\text { vs. term piglets }\end{array}$ \\
\hline Eriksen et al. (50) & $\begin{array}{l}\text { Dopamine } 10,25,40 \\
\mathrm{mcg} / \mathrm{kg} / \mathrm{min}\end{array}$ & $\begin{array}{l}\text { Newborn piglets; Acutely } \\
\text { instrumented; Hypotension; } \\
\text { Prospective, randomized (dose) } \\
\text { study }\end{array}$ & $\begin{array}{l}\text { Dopamine did not impair cerebral } \\
\text { autoregulation }\end{array}$ & $\begin{array}{l}\text { Dopamine tended to } \\
\text { improve cerebral } \\
\text { autoregulation at low blood } \\
\text { pressures }\end{array}$ \\
\hline Mielgoet al. (51) & $\begin{array}{l}\text { Dobutamine }{ }^{*} 10-15 \text { and } \\
15-20 \mathrm{mcg} / \mathrm{kg} / \mathrm{min} \times \\
30 \mathrm{~min}\end{array}$ & $\begin{array}{l}\text { Newborn piglets; Acutely } \\
\text { instrumented; } \\
\text { Hypoxia-reoxygenation; } \\
\text { Prospective, randomized, blind, } \\
\text { cross-over study }\end{array}$ & $\begin{array}{l}\text { Both doses increased } \mathrm{HR} \text { and } \mathrm{CO} \text { but not } \\
\text { stroke volume nor SAP; } 10-15 \mathrm{ug} / \mathrm{kg} / \mathrm{min} \\
\text { dobutamine increased oxygen } \\
\text { consumption }\end{array}$ & $\begin{array}{l}{ }^{\star} \mathrm{A} \text { new pediatric } \\
\text { dobutamine formulation }\end{array}$ \\
\hline
\end{tabular}

SAP and PAP, systemic and pulmonary arterial pressure, respectively; CO, cardiac output; HR, heart rate.

it may be counterbalanced by an increase in left ventricular wall stiffness, time to maximal contraction, and relaxation time $(79,80)$. Within the context of these myocardial changes, the increased contractility may be most effective at the slower heart rate and chronotropic effect of vasoactive medications may not be beneficial but detrimental. Alpha-adrenergic sensitivity may increase during hypothermia, but $\beta_{1}$ adrenergic responses are variable during $\mathrm{TH}$ depending on the experimental model and temperatures investigated. Furthermore, $\mathrm{TH}$ also slows the oxygen consumption of the tissues and affects the drug metabolism (54). The Pharmacool study is currently evaluating the effects of therapeutic hypothermia on a myriad of drugs used for the asphyxiated neonatal population, including antihypotensive medications (81). During rewarming, CO and systolic BP will increase while the simultaneous decrease in systemic vascular resistance will be reflected in a decreased diastolic and mean BP (82).

Dopamine, dobutamine, and epinephrine are frequently administered to neonates and the use of milrinone, norepinephrine and vasopressin has increased in recent years. Of note, fluid bolus is commonly given to hypotensive neonates first, followed by cardiovascular supportive treatment. However, the administration of fluid bolus may be harmful in asphyxiated neonates (83). Conversely, in neonates with hemorrhagic hypovolemia, such as asphyxia associated with placental abruption, tempered fluid or blood administration may be needed for proper hemodynamic responses toward inotropes or vasopressors. While hypoxia-reoxygenation injury can increase the permeability of the peripheral microvasculature and potentially exacerbate fluid shifts, TH may at least in part counteract these effects (84). Therefore, the intravascular volume status must be carefully assessed prior to fluid therapy $(85,86)$.

\section{CATECHOLAMINES}

Catecholamines including dopamine, dobutamine, epinephrine and norepinephrine have a catechol and amine group in their chemical structure. Through the activation of adrenergic (and/or 
dopaminergic and serotoninergic) receptors in the sympathetic nervous system, cardiomyocytes, vascular smooth muscle cells, and other extravascular parenchymal cells, catecholamines produce complex cardiovascular, renal and endocrine actions (87). However, the expression of cardiovascular adrenoreceptors can be altered in critical illness, prolonged use of catecholamine, and relative adrenal insufficiency, in addition to immaturity and dysmaturity (88). The $\beta-1$ adrenoreceptors could be downregulated, $\beta$-2 adrenoreceptors uncoupled from adenylyl cyclase, and adenylyl cyclase and cAMP production decreased in the failing myocardium (89).

\section{DOPAMINE}

Dopamine is the most commonly used antihypotensive infusion used in neonates, due to the frequent use in the preterm population (90). Dopamine, an endogenous catecholamine precursor of norepinephrine, has sympathetic and neuroendocrine properties. Its pharmacological actions are through the direct stimulation of dopaminergic and adrenergic receptors or indirect stimulation of dopamine 2 receptor with release of norepinephrine stored in the peripheral sympathetic nerve endings $(89,91)$. Given the finite norepinephrine stores of neonates, dopamine may lose its effectiveness over time as the indirect inotropic pathway become depleted. Thus, dopamine should not be chosen for long-term inotropic therapy (92).

There have been extensive discussion regarding effects of dopamine at different doses, different gestations and ages (93). The controversy is the dose-dependent stimulation of dopaminergic and adrenergic receptors at "low" $(<2-4$ $\mathrm{mcg} / \mathrm{kg} / \mathrm{min})$, "moderate" (4-10 $\mathrm{mcg} / \mathrm{kg} / \mathrm{min})$, and "high" $(10-20 \mathrm{mcg} / \mathrm{kg} / \mathrm{min})$ doses with "renal," chronotropic/inotropic and vasoconstrictive effects, respectively, in neonates (94-96). There is little information available regarding the expression and functionality of adrenergic and dopaminergic receptors expressed in the cardiovascular system including renal, mesenteric, and coronary vasculatures, in asphyxiated neonates. The response to dopamine has a high interpatient variability, which is in part related to the overlapping stimulation of dopaminergic and adrenergic receptors, and can be markedly decreased in ill neonates $(97,98)$. Padbury et al. studied pharmacokinetics of dopamine in critically ill neonates with different pathophysiological conditions, including 7/13 with a diagnosis of asphyxia, and observed variable responses to the same dose in different patients (99). Thus, the dosage of dopamine should be titrated according to the hemodynamic effect but not standardized dosing regimen.

Much of our evidence was inferred from findings from animal studies and a small number of clinical trials in the neonatal population. There is a lack of consistent effect of dopamine on CO, BP, and organ perfusion in animal studies $(33,37$, $49,50)$. Based on our search, we found only one randomized controlled study that compared dopamine $(2.5 \mathrm{mcg} / \mathrm{kg} / \mathrm{min})$ to placebo in asphyxiated term neonates (11). Despite the pressor effect after dopamine infusion, echocardiographic indices of CO, morbidity or mortality were not different between groups. In a study of 11 asphyxiated neonates, although CO, stroke volume, BP and heart rate were increased after dopamine infusion (4$10 \mathrm{mcg} / \mathrm{kg} / \mathrm{min}, n=6$ ), no temporal hemodynamics were provided for comparison in 5 untreated infants (12). There is insufficient evidence to support using dopamine to improve outcome, morbidity and mortality in term infants with suspected asphyxia (100). Interestingly, Drury et al. demonstrated that dopamine infusion (4-40 $\mathrm{mcg} / \mathrm{kg} / \mathrm{min}$ titrated according to mean arterial BP) delayed but did not prevent terminal hypotension after severe asphyxia in near-term fetal sheep [517 (range 240715 ) vs. 106 (range 23-497) min of saline-treated controls after the start of infusions] (47). Furthermore, there might be an adverse effect with the use of high dose dopamine. Increased PAP/SAP ratio leading to right to left ductal shunting with potentially aggravating hypoxemia has been observed in asphyxiated newborn piglets and premature infants $(33,37,101)$. Compared to higher dopamine doses, the addition of epinephrine to dopamine had a more favorable lower PAP/SAP ratio in an asphyxia-reoxygenation piglet model (48).

Although a piglet model demonstrated no net change in myocardial oxygen delivery, a study in neonates after their Norwood surgery demonstrated that myocardial oxygen use was greater than delivery after a dose of $5 \mathrm{mcg} / \mathrm{kg} / \mathrm{min}(16,33)$. The regional hemodynamic effects of dopamine in asphyxiated newborns have been uncertain although there was increased mesenteric blood flow at high dose $(>10 \mathrm{mcg} / \mathrm{kg} / \mathrm{min})$ in newborn piglets with asphyxia. The vasodilatory action of dopamine in the mesenteric vasculature suggests the activation of $\beta-2$ adrenergic (unlikely dopaminergic) receptors at high doses due to sub-optimal or impaired receptor functionality under hypoxia-reoxygenation. Further, it remains controversial if dopamine affects cerebral autoregulation $(50,102)$.

Although dopamine may cause chronotropy with tachycardia which may increase $\mathrm{CO}$, its inotropic effect remains to be determined. We consider dopamine predominantly a vasopressive drug which could be considered for the treatment of low BP in the presence of a normal CO state. Indeed, there should be consideration of effects and interpatient variability at different doses and an understanding that high doses may increase the ventricular afterload and potentiate right to left shunting across the ductus arteriosus. Nevertheless, despite its fast onset of action and user familiarity, the lack of reliable inotropy in the face of potential excessive vasoconstriction and its ability to potentiate PHT do not make it an attractive first choice as the cardiovascular supportive agent for asphyxiated neonates.

\section{DOBUTAMINE}

Dobutamine is a synthetic catecholamine that has direct adrenoreceptor agonism. It acts predominantly on $\beta-1$ adrenoreceptors to increase cardiac contractility with improved ejection times and shortening fraction and often will increase heart rate, especially at mid to higher doses (103). There is little peripheral vasoconstriction and potentially mild peripheral vasodilation and afterload reduction $(34,103)$. A recent literature review on the pharmacology of dobutamine indicated that heart 
rates in neonatal studies increased an average of $7-15$ beats/min (or $5-12 \%$ change) with the average dose of approximately 5 $\mathrm{mcg} / \mathrm{kg} / \mathrm{min}$ mitigating a significant heart rate change (103). At doses with associated tachycardia or $>10 \%$ of the baseline heart rate, dobutamine may increase myocardial oxygen consumption which renders its effect on CO less efficient and potentially aggravates cardiac dysfunction in the presence of unmatched oxygen delivery. As dobutamine acts directly as a catecholamine, long-term use will result in tachyphylactic down regulation of catecholamine receptors.

While dobutamine is not a common medication used in neonates with isolated hypotension, it is often used in asphyxiated neonates with low $\mathrm{CO}$ or perfusion states with or without hypotension $(90,104)$. Two small studies of 6 term asphyxiated neonates and 13 critically ill neonates respectively, demonstrated that dobutamine at $2.5-10 \mathrm{mcg} / \mathrm{kg} / \mathrm{min}$ increased $\mathrm{CO}$ and heart rate but not necessarily arterial BP $(13,105)$. Interestingly, dobutamine has been shown to be more effective at increasing $\mathrm{CO}$ during rewarming $\left(35-37^{\circ} \mathrm{C}\right)$ than during cooling temperatures $\left(33^{\circ} \mathrm{C}\right)$ in a small study of neonates receiving $\mathrm{TH}$ for asphyxia (78). This temperature dependence has also been demonstrated in ventricular trabeculae tissue studies and may be further elucidated with the Pharmacool results (106).

While neonatal animal studies of dobutamine during normoxia demonstrated a dose-dependent increase in $\mathrm{CO}$, through both chronotropy and inotropy, with a mild increase in cerebral flow, an improved $\mathrm{CO}$ was replicated only at 20 $\mathrm{mcg} / \mathrm{kg} / \mathrm{min}$ without significant increases in regional perfusion in an asphyxia-reoxygenation piglet model $(35,36,38)$. A recent asphyxia-reoxygenation piglet study affiliated with the NeoCirc Trial utilized a new dobutamine formulation and demonstrated increases in $\mathrm{CO}$, in the face of unchanged stroke volume, oxygen delivery, and oxygen consumption with improved peripheral tissue oxygenation index and peripheral intravascular oxygenation at doses of $10-15 \mathrm{mcg} / \mathrm{kg} / \mathrm{min}$ (51).

Dobutamine, with inotropic and mild afterload reduction properties, has a relatively quick onset of action (minutes) in comparison to milrinone (hours), another drug with similar properties; thus, is a reasonable first line therapy for asphyxiated babies who have clinical or echocardiographic decreases in $\mathrm{CO}$ and increased systemic vascular resistance or maintained BP pressure. Dobutamine does not have the significant metabolic effects of hyperglycemia and hyperlactatemia that can be seen with epinephrine. Therefore, for those clinicians who use serial lactate measurement as a sign of improvement in tissue perfusion, the inotropy of dobutamine is not accompanied by an increase in lactate to the same magnitude of the inotropic dose of epinephrine. However, the lack of significant vasopressive action of dobutamine cautions its use, as a single agent, in certain asphyxiated neonates with normal or borderline BP as the BP could further be reduced. Indeed, if vasopressive action is required during dobutamine infusion, the addition of dopamine, norepinephrine or vasopressin may be considered (4). Further the use of dobutamine should be cautious in neonates with preexisting tachycardia or ventricular outflow tract obstruction (e.g., asphyxia in an infant of diabetic mother or with hypertrophic cardiomyopathy) because of the aggravated $\beta$ - 1 adrenoreceptors agonism.

\section{EPINEPHRINE}

Epinephrine is an endogenous catecholamine and it stimulates both $\alpha(-1$ and -2$)$ and $\beta(-1$ and -2$)$ adrenoreceptors, which is believed to have dose-dependent hemodynamic effects. In neonates, at low doses $(0.02-0.1 \mathrm{mcg} / \mathrm{kg} / \mathrm{min})$ epinephrine acts predominantly on the $\beta-1$ and $\beta-2$ adrenoreceptors and has positive inotropic and chronotropic actions (97). We also demonstrated limited vasodilation in pulmonary, renal and mesenteric vasculatures of asphyxiated-reoxygenated newborn piglets (42). Similar observations in the systemic and pulmonary hemodynamics with improved $\mathrm{CO}$, increased $\mathrm{BP}$ and lowered PAP/SAP ratio (favorable reversal of rightto-left ductal shunting in PHT), were found in studies using newborn animals $(33,39,40)$. At doses $>0.1 \mathrm{mcg} / \mathrm{kg} / \mathrm{min}$, the $\alpha-1$ adrenoreceptor effect of vasoconstriction predominates over the $\beta$ adrenergic effect resulting in decreasing blood flow to the gut and kidneys. This may further increase the afterload of an already compromised neonatal heart and tissue perfusion. Indeed, high dose epinephrine $(>0.5 \mathrm{mcg} / \mathrm{kg} / \mathrm{min}$, equivalence of a resuscitation dose of $10 \mathrm{mcg} / \mathrm{kg}$ every $20 \mathrm{~min}$ ) may lead to decreasing CO due to coronary vasoconstriction and disorganized energy utilization.

Epinephrine infusions are commonly associated with hyperglycemia and hyperlactatemia due to increased glycogenolysis via the activation of $\beta-2$ adrenergic receptors. This may confound the use and interpretation of lactate during epinephrine infusion as lactate is generally known as a marker of the anaerobic glycolytic breakdown of glucose to pyruvate exaggerated by $\alpha$-adrenergic vasoconstriction and imbalanced oxygen metabolism vs. as a byproduct of accelerated aerobic glycolysis (27). Studies indicate that increases in glucose and lactate were related to increasing doses of epinephrine infusion but not associated to age, birthweight or glucose infusion rate and were often delayed in comparison to elevation in BP or heart rate (27). Associated hyperglycemia may necessitate insulin infusion and the need for more vascular access points if infusion capability issues arise. Interestingly, Basu et al. found that while hypoglycemia and hyperglycemia were independently associated with death and/or severe neurodevelopmental disability at 18 months in infants with hypoxic-ischemic encephalopathy, they further observed that hyperglycemia in those infants randomized to $\mathrm{TH}$ had reduced risk of unfavorable outcome in a post-hoc analysis of 234 infants enrolled in the CoolCap Study from 1999 to 2002 (ADC 2016 and ADC 2017) (107, 108). This highlights the importance of glucose homeostasis and its cerebral consequences and subsequent neurodevelopmental outcome. In the choice and administration of inotropes in asphyxiated neonates, euglycemia needs to be ensured. Other adverse cellular effects with epinephrine infusion have been reported including myocardial oxidative stress, sarcolemma rupture and increased cytoplasmic calcium deposits $(32,40)$. 
Epinephrine is considered for hypotensive asphyxiated neonates when there is a concern of decreased $\mathrm{CO}$ with decreased systemic vascular resistance due to vasoplegia. Given the increases in heart rate and myocardial contractility, clinicians should ensure that volume status is adequate prior to starting epinephrine. It is also cautious to use epinephrine in the face of ventricular outflow tract obstruction. Clinicians need to be cognizant of the metabolic increases in lactate as it may change their ability to follow serial lactates for signs of hemodynamic or oxygen utilization improvement. Interestingly, Manouchehri et al. demonstrated that the use of epinephrine in combination with dopamine improved systemic and regional hemodynamic effects with reduced PAP/SAP ratio, which was deficient in high-dose dopamine infusion (48). Further studies are needed to evaluate the innovative proposal of starting epinephrine infusion at low doses $(0.05 \sim 0.1$ $\mathrm{mcg} / \mathrm{kg} / \mathrm{min}$ ) as the initial choice of a mono-pharmacological, cardiovascular supportive therapy in those asphyxiated hypotensive neonates with evidence of low $\mathrm{CO}$ and poor vessel tone.

\section{MILRINONE}

Milrinone is a bipyridine derivative that inhibits phosphodiesterase type III on cAMP degradation leading to increased intracellular calcium concentration (52). It is named as an inodilator because of intracellular calcemic actions in cardiac myocytes (improved contractility) and vascular smooth cells (vasodilation, both systemic and pulmonary). Milrinone increases myocardial contractility through a cyclic AMPmediated increase in trans-sarcolemmal calcium flux and also allows calcium resequestration into the sarcoplasma reticulum, causing peripheral vasodilation, and improved actin-myosin dissociation during diastole; thus, earning its classification as an inotrope and lusitrope (109). Bianchi et al. demonstrated significant increases in $\mathrm{CO}$ within $6 \mathrm{~h}$ of milrinone infusion in a prospective study of preoperative neonates with congenital heart defects at an average age of $12 \mathrm{~h}$ of life (28). Milrinone may have the advantage over some other inotropes regarding a possible preservation of myocardial contractile response with its ongoing use for the post-adrenoreceptor effects, which also explains its gradual onset of action $(25,89,110)$. Tachycardia, hypotension, and thrombocytopenia have been reported as side effects, with transient hypotension occurring more frequently in the setting of compromised vascular volume and/or bolus loading doses $(111,112)$.

The combined inotropic and pulmonary vasodilatory effects of milrinone, as facilitated by its lusitrophic action on diastolic dysfunction, is advantageous in asphyxiated neonates with impaired myocardial contractile function and PHT, resulting in improved $\mathrm{CO}$ and oxygenation. Interestingly, milrinone has been shown to dilate the ductus arteriosus in rats because of the phosphodiesterase type III inhibition (43). These hemodynamic actions may prove to be important in the abnormal cardiovascular state of asphyxiated neonates and make milrinone a potential medication for asphyxia with PHT (113).
The half-life of milrinone is approximately $4 \mathrm{~h}$ in neonates who have decreased clearance $(32,109)$. While the renal clearance of milrinone depends on gestational and chronological age (up to 10 days) in term neonates, dose adjustments in the presence of significant renal impairment, prematurity, or in the first few days after birth may be warranted to avoid an accumulation of dose and accompanying side effects (30).

Over the last decade there has been an increasing use of milrinone in neonates predominantly for cardiopulmonary dysfunction in the context of PHT and low CO in diseases including asphyxia, peri-operative period of cardiac surgery, and congenital diaphragmatic hernia $(14,15,17,28,111,114-$ 116). In newborn piglets with asphyxia, dose-related increases in systemic and regional (carotid and intestinal) hemodynamics without significant effects on chronotropy, BP and PHT were observed with milrinone infusion at $0.25-0.75 \mathrm{mcg} / \mathrm{kg} / \mathrm{min}$ (41). Despite a lack of quality data found by a 2015 Cochrane review to recommend its use for PHT in neonates, small feasibility studies have shown milrinone increased performances of both left and right ventricles, and improved oxygenation (29, 112, 114, 116, 117).

Although milrinone is emerging as an attractive therapy in neonates with cardiovascular dysfunction compromised with PHT, clinical studies of high quality are mandatory to examine its therapeutic and prophylactic uses in asphyxiated neonates with PHT who have or may develop hypotension and low $\mathrm{CO}$ and poor tissue perfusion (118-120).

\section{NOREPINEPHRINE}

Norepinephrine is an endogenous sympathomimetic amine that acts primarily on vascular and myocardial $\alpha-1$ receptors with a mild $\beta-1$ and minimal $\beta-2$ adrenoreceptors stimulation. Therefore, norepinephrine has predominant peripheral vasoconstriction with minimal inotropic effect (121). Indeed, the concern of myocardial vasoconstriction and oxygen delivery as well as the afterload increase in the presence of myocardial dysfunction may preclude the use of norepinephrine as the first drug of choice in asphyxiated neonates with suspected increased or normal vascular tone.

Norepinephrine's ability to increase systolic pressure also improves coronary systolic BP which is important to the coronary blood flow of the right ventricle especially during acute right heart failure as can be seen when exposed to the high afterload of PHT $(122,123)$. Thus, in addition to increasing BP, norepinephrine may assist in decreasing pulmonary hypertension while improving cardiac performance of the left and right ventricle. However, on a cautious note, excessive systemic vasoconstriction from norepinephrine infusion can further impair ventricular contractility, in addition to increased myocardial oxygen demand, when ventricular function is not concurrently supported.

To date, the clinical use of norepinephrine in term neonates has been predominantly reserved for hypotensive neonates who have refractory shock or low CO state, especially those with severe septicemia and post cardiac surgery or right ventricular stress (19). In 22 term neonates with refractory septic shock and 
receiving moderate to high doses of dopamine or dobutamine, norepinephrine significantly increased mean BP (36 \pm 5 to $51 \pm$ $7 \mathrm{mmHg}$ ), improved oxygenation measures and decreased serum lactate within hours (20). The increase in oxygenation could be related to differential effects of norepinephrine at the systemic and pulmonary vasculature resulting in a favorable increase in systemic-to-pulmonary arterial pressure ratio.

Oualha et al. reported pharmacokinetic and pharmacodynamic variabilities during the infusion of norepinephrine $(0.5-3 \mathrm{mcg} / \mathrm{kg} / \mathrm{min})$ in 11 neonates (124). They suggested that birthweight, age and severity of illness might affect the production and clearance of norepinephrine, which are dependent on enzymatic maturation. The mean doses used in this study were on the high end of dosing regimens in comparison to pediatric or adult doses used in current practice and judicious dosing commenced earlier in shock courses may allow for lower doses or earlier discontinuation of other inotropes as seen in retrospective reviews (125).

Norepinephrine is often used as a second or third line antihypotensive drug. In combination with dobutamine or milrinone, it allows for vascular tone support, and may augment coronary perfusion and support the right ventricle myocardium in the case of asphyxia with severe PHT and right heart failure (123). The addition of norepinephrine $0.02-0.05$ $\mathrm{mcg} / \mathrm{kg} / \mathrm{min}$ might reduce epinephrine dosages (leading to less hyperlactatemia and hyperglycemia) in asphyxiated neonates with severe cardiac dysfunction and vasoplegia. Further studies are required to evaluate the therapeutic role of this combined use of $\alpha$ and $\beta$ adrenoreceptors agonists.

\section{VASOPRESSIN}

Vasopressin, or arginine vaspressin (AVP), is an endogenous substance with diverse actions that relate to the location of tissue specific vasopressin subtype receptors, but is most commonly used for its vasoconstrictor properties. The V1 subtype mediates vasoconstriction in vascular smooth muscle except within the pulmonary circulation where it potentiates the release of nitric oxide causing vasodilation. V1 receptors are also found on hepatocytes and platelets, which could result in platelet aggregation and glycogenolysis. The V2 subtype regulates water reabsorption, while V3 effects adrenocorticotrophic hormone $(\mathrm{ACTH})$ release (126-128). Purinergic P2 receptors are also found in the myocardium and contribute to selective coronary dilation. During exogenous infusion, the potent vasoconstrictive effects predominate (129). In neonatal studies, dosages of AVP ranged between $0.0002-0.002$ units $/ \mathrm{kg} / \mathrm{min}$ in keeping with manufacturer recommendations $(130,131)$.

Vasopressin, in the presence of ACTH, is associated with increased adrenal cortisol release (132). The use of vasopressin has been increasing over the past 10 years in neonates with sepsis, catecholamine and corticosteroid resistant shock, hypotension from ventricular outflow tract obstructions, post cardiopulmonary bypass for congenital cardiac surgery and PHT $(18,24,130,133,134)$. It is speculated that endogenous AVP is depleted in these critical vasoplegic conditions (135,
136). Low-dose AVP infusion selectively dilated pulmonary, coronary, and even cerebral vasculature under hypoxic state, but vasoconstricted other vascular beds (31, 137-139). Cheung et al. demonstrated that vasopressin treatment causes a dosedependent, baro-specific effect, while preserving cardiac function and cerebral and mesenteric hemodynamics in asphyxiated newborn piglets during the infusion of vasopressin at low doses (0.00008-0.0003 units $/ \mathrm{kg} / \mathrm{min})$ (31). Pelletier et al. further showed the low-dose vasopressin infusion improved $\mathrm{CO}$ and mesenteric perfusion using the swine model of neonatal asphyxia with lowered oxidative stress markers similar to those observed in animals with dobutamine infusion at 20 $\mathrm{mcg} / \mathrm{kg} / \mathrm{min}$ (46). Retrospective studies also suggest a potential role for vasopressin in neonates with congenital diaphragmatic hernia or PHT with catecholamine resistant hypotension, when it was used as an adjunctive antihypotensive therapy at 0.0001-0.005 units $/ \mathrm{kg} / \mathrm{min}(26,140)$. Improvements in mean arterial BP, oxygenation index, heart rate, pulmonary-to-systemic shunts, inotrope scores and the need for ECMO have been found.

However, despite increased BP, decreased inotropic support and variable effects in end-organ perfusion, clinical studies of vasopressin use did not demonstrate an increase in survival $(126,141)$. Given that vasopressin is often used as a rescue therapy for profoundly hypotensive neonates late in the shock process, this may not be surprising. Of note, in a pediatric randomized controlled trial that did not include neonates, a trend toward increased mortality was observed in children treated with low-dose vasopressin (142).

Adverse effects of vasopressin that have been reported in neonatal studies include significant hyponatremia, transient decrease in platelet count, and liver necrosis $(24,26,133,143)$. Although, limb necrosis has been reported in the meta-analysis and Cochrane review, these predominantly occurred with the use of terlipressin but Choong's pediatric randomized study reported an increase in the vasopressin group $(26,142)$.

The therapeutic role of vasopressin in asphyxiated neonates with profound vasoparesis and hypotension and/or PHT is unclear. Vigilance must be taken to watch for hyponatremia and evidence of worsening cardiac dysfunction in the face of vasoconstriction.

\section{LEVOSIMENDAN}

Levosimendan is a "calcium-sensitizing inotrope" that acts to increase cardiac contractility by binding to and stabilizing calcium-saturated cardiac Troponin C. This inotropic action of levosimendan differs from that of catecholamines or milrinone which increase the trans-sarcolemmal calcium flux during systole. Consequently, the increased $\mathrm{CO}$ by levosimendan is not associated with higher myocardial oxygen consumption, which is commonly seen with catecholamines administration (144). Levosimendan partially inhibits phosphodiesterase type III and activates ATP-sensitive potassium channels, resulting in mild lusitropy and vasodilation, respectively (thus an inodilator) (145-147). These additional properties of levosimendan may 
cause systemic and pulmonary vasodilation and increase coronary blood flow (144).

Levosimendan is mostly used in neonates and infants with heart failure or myocardial stunning (21-23, 148). However, the hemodynamic effects and dosing regimen of levosimendan was seldom described in detail in asphyxiated neonates. The limited literature and experience may therefore render the use of levosimendan mostly as an adjunctive cardiovascular supportive therapy of critically ill neonates in countries where its clinical application is approved. Using a swine model of neonatal asphyxia, we found that levosimendan at $0.1-0.2 \mathrm{mcg} / \mathrm{kg} / \mathrm{min}$ had only a modest improvement in $\mathrm{CO}$ and carotid blood flow without significant hypotension, tachycardia, or worsening of PHT (44). This suggests that the calcium sensitizing action of levosimendan may not be effective in the neonatal myocardium after asphyxia, thus undermining its role as a monotherapy in asphyxiated neonates.

Given that cAMP-increasing inotropes increase intracellular calcium and that levosimendan sensitizes the myofibrils to calcium, it is speculated that the two classes may have a synergistic effect. Nevertheless, the therapeutic role for levosimendan in neonatal asphyxia deserves further investigations as an adjunctive therapy to minimize the dosage and side effects of catecholamines used.

\section{HYDROCORTISONE}

An intact hypothalamo-pituitary-adrenal axis function is critical for shock reversal. Steroid has an important role in the function of adrenergic receptors with enhanced coupling and adenylate cyclase activity (149). Steroids may also up-regulate myocardial and vascular adrenoreceptors (150). Paired with their ability to increase circulating catecholamines by inhibiting degradation, steroids can augment catecholamine action. Smooth muscle calcium availability is also increased improving vessel tone and decreasing capillary leak.

In neonatal asphyxia, adrenal insufficiency and or adrenal hemorrhage has been reported (151). Indeed, adrenal hemorrhage may be found in neonates with severe asphyxia and those with poor outcome. In asphyxiated newborn piglets, Chapados et al. observed a delayed cortisol response to standard adrenocorticotrophin (ACTH, Cortrosyn $4 \mu \mathrm{g} / \mathrm{kg}$ ) stimulation whereas the resuscitation with $100 \%$ but not $21 \%$ oxygen had a sub-optimal increase in cortisol levels (152). This suggests a possible reduction in the adrenal reserve and dysfunctional hypothalamo-pituitary-adrenal axis in the asphyxiated newborn piglets, especially when a high oxygen concentration was used in the resuscitation. They suggested that the preserved cortisol response in $21 \%$ oxygen resuscitation was related to the expression of steroidogenic factor 1 in the adrenal glands.

Although the clinical significance of cortisol response to $\mathrm{ACTH}$ in neonates is uncertain, a poor response to a standard ACTH stimulation test (an increase in plasma cortisol of $<250$ $\mathrm{nmol} / \mathrm{l}, 1 \mathrm{~h}$ post injection) has been associated with higher short-term mortality in adults and children with septic shock $(153,154)$. Interestingly, low serum cortisol levels in critically ill term neonates who subsequently respond appropriately to exogenous ACTH may also indicate that some neonates have inadequate hypothalamic-pituitary-adrenal signaling with intact adrenal function (155). Thus, the physiological and pharmacological administration of steroids or hydrocortisone seems like a reasonable and trendy modality to provide cardiovascular support (156). Fernandez et al. showed that hypotensive infants harboring low cortisol levels $(<414 \mathrm{nmol} / \mathrm{l}$ in stress) showed an improvement in their hemodynamic parameters when given hydrocortisone for their shock (1-2 $\mathrm{mg} / \mathrm{kg} /$ day) compared to infants with normal cortisol levels (155). It indicates that hydrocortisone administration to reverse (catecholamine-) refractory shock can be beneficial only in those with an impaired adrenal function. However, there is limited information regarding the therapeutic roles of hydrocortisone therapy (adrenal dysfunction modulation and or anti-inflammatory action) in asphyxiated newborns (151). Furthermore, clinicians should attend to the potential side effects of hydrocortisone including hyperglycemia, gastrointestinal hemorrhage, and increased pulmonary arterial pressure for short-term administration of hydrocortisone (157).

\section{FINAL THOUGHTS}

Asphyxiated neonates have unique pathophysiological and pharmacological conditions for shock with regional hypoperfusion which interplay with the hemodynamic effects of $\mathrm{TH}$, respiratory state and ventilatory support. In addition to clinical assessment, application of evaluating tools of cardiac function, and tissue oxygenation will enhance our understanding of the pathophysiology of hypotension and /or low CO in these critically ill neonates. Therefore, individualized cardiovascular supportive therapy can be provided based on pharmacological and patho-physiological understanding of the neonate, therapy, and concurrent interventions accordingly (Figure 1)

In this review, the asphyxiated neonate develops "hypotension" and/or "low CO" which we refer to clinical condition(s) with tissue perfusion deficits as a result of low BP and or decreased systemic perfusion, respectively. The hypotensive and low $\mathrm{CO}$ states therefore require respective therapies. Despite the common occurrence of hypotension and low $\mathrm{CO}$ in asphyxia, some neonates have hypotension with normal CO state or reduced systemic blood flow without severe hypotension (4). The cardiovascular supportive therapies are directed toward the correction of specific perfusion deficits (Figure 2). In view of potential adverse effects of cardiovascular supportive therapy, especially at high dosages, the lowest effective dosage of medications should be used to provide optimal BP for adequate organ (e.g., cerebral or renal) perfusion and systemic oxygenation, and optimal $\mathrm{CO}$ without tissue perfusion deficits and metabolic acidosis. Furthermore, the regional hemodynamic effects of medications also play an important role in the choice of cardiovascular supportive therapies.

We identified pre-clinical studies but very few clinical studies conducted to examine systemic and regional hemodynamic effects of various cardiovascular supportive medications in this 


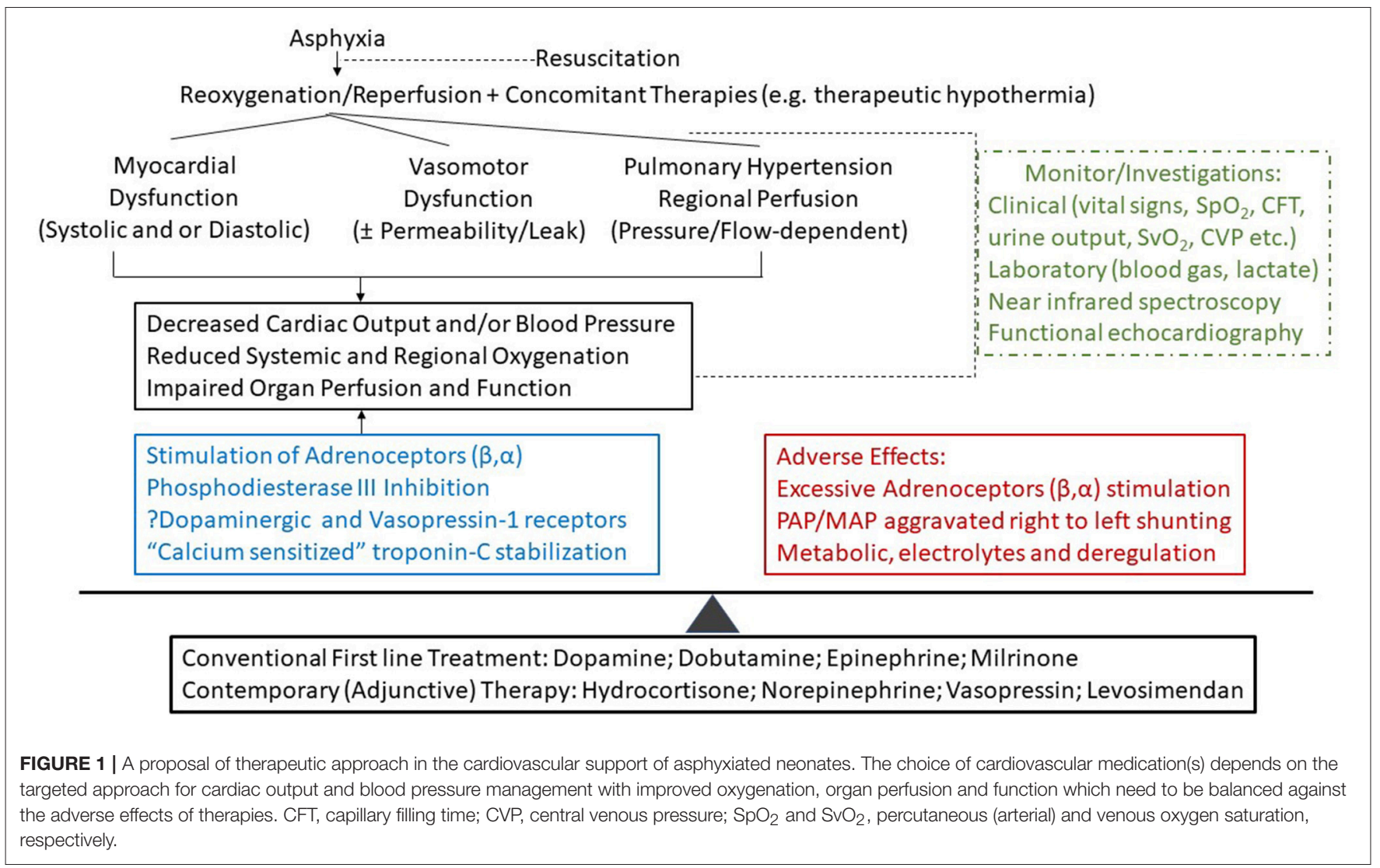

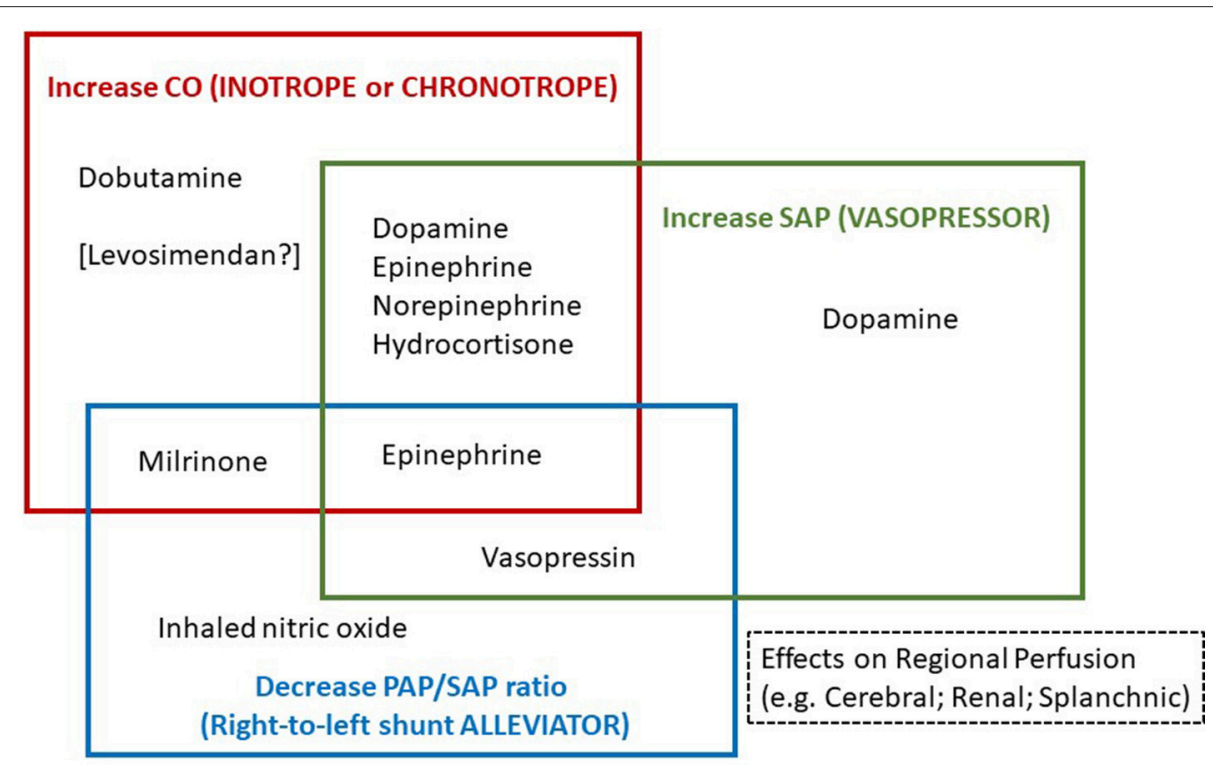

FIGURE 2 | Medications categorized according to three specific cardiovascular supportive functions; (a) to increase cardiac output (CO), (b) to increase systemic arterial pressure (SAP), or (c) to decrease pulmonary arterial pressure (PAP) to SAP ratio.

critical population. While the interpretation and translation of the findings from animal studies require great caution, the studies provide important information that may help tailor appropriate medical cardiovascular support that maintains BP, $\mathrm{CO}$, and regional perfusion. It is imperative to note that, treating hypotension, as opposed to poor CO or decreased blood flow, has 
not convincingly improved mortality and morbidity $(93,96,158)$. Targeting CO and regional perfusion may be the appropriate approach for improving the outcome of these critically ill neonates with asphyxia. The resultant cardiovascular effects of medications should be balanced against adverse effects including excessive vasoconstriction, tachycardia, and metabolic effects associated with the collateral receptor(s) activation at high doses. It is also important to attend to the metabolic effects of inotropes, e.g., hyperglycemia and hyperlactatemia of epinephrine infusion given euglycemia and normal lactate levels are critical for clinical care and predictive for neurodevelopmental outcomes.

The information regarding the co-administration of catecholamines is scare. The choice of catecholamines will depend on the synergetic activation of adrenoceptors and signaling pathway in myocardial contractile function, systemic

\section{REFERENCES}

1. Perinatal morbidity. Report of the Health Care Committee Expert panel on Perinatal Morbidity. National Health and Medical Research Council. Australian Government Publishing Service. (1995)

2. Martin-Ancel A, Garcia-Alix A, Gaya F, Cabañas F, Burgueros M, Quero J. Multiple organ involvement in perinatal asphyxia. J Pediatr. (1995) 127:78693.

3. van Bel F, Walther FJ. Myocardial dysfunction and cerebral blood flow velocity following birth asphyxia. Acta Paediatr Scand. (1990) 79:756-62. doi: 10.1111/j.1651-2227.1990.tb11551.x

4. Giesinger RE, Bailey LJ, Deshpande P, McNamara PJ. Hypoxic-ischemic encephalopathy and therapeutic hypothermia: the hemodynamic perspective. J Pediatr. (2017)180:22-30. doi: 10.1016/j.jpeds.2016.09.009

5. Shah P, Riphagen S, Beyene J, Perlman M. Multiorgan dysfunction in infants with post asphyxial hypoxic ischemic encephalopathy. Arch Dis Child Fetal Neonatal Ed. (2004) 89:152-5. doi: 10.1136/adc.2002.023093

6. Perlman JM, Tack Ed, Martin T, Shackelford G, Amon E. Acute systemic organ injury in term infants after asphyxia. Am J Dis Child. (1989) 143:61720.

7. Kluckow M, Evans N. Superior vena cava flow in newborn infants: a novel marker of systemic blood flow. Arch Dis Child Fetal Neonatal Ed. (2000)82:F182-7. doi: 10.1136/fn.82.3.F182

8. Sood BG, McLaughlin K, Cortez J. Near-infrared spectroscopy: applications in neonates. Semin Fetal Neonatal Med. (2015) 20:164-72. doi: 10.1016/j.siny.2015.03.008

9. Batton B, Li L, Newman NS, Das A, Watterberg KL, Yoder BA, et al. Use of antihypotensive therapies in extremely preterm infants. Pediatrics (2013) 131:e1865-73. doi: 10.1542/peds.2012-2779

10. Burns ML, Stensvold HJ, Risnes K, Guthe HJ, Astrup H, Nordhov $\mathrm{SM}$, et al. Inotropic therapy in newborns, a population-based national registry study. Pediatr Crit Care Med. (2016) 17:948-56. doi: 10.1097/PCC.0000000000000898

11. DiSessa TG, Leitner M, Ti CC, Gluck L, Coen R, Friedman WF. The cardiovascular effects of dopamine in the severely asphyxiated neonate. $J$ Pediatr. (1981) 99:772-6. doi: 10.1016/S0022-3476(81)80409-X

12. Walther FJ, Siassi B, Ramadan NA, Wu PYK. Cardiac output in newborn infants with transient myocardial dysfunction. J Pediatr. (1985) 107:781-5. doi: 10.1016/S0022-3476(85)80417-0

13. Devictor D, Verlhac S, Pariente D, Huault G. Hemodynamic effects of dobutamine in asphyxiated newborn infants. Arch Fr Pediatr. (1988) 45:46770 .

14. Chang AC, Atz AM, Wernovsky G, Burke RP, Wessel DL. Milrinone: systemic and pulmonary hemodynamic effects in neonates after cardiac surgery. Crit Care Med. (1995) 23:1907-24. doi: 10.1097/00003246-199511000-00018 and pulmonary vasomotor regulation, potentially without excessive adrenoceptors activation of high-dose monotherapy. Pharmacodynamic and pharmacokinetic interactions in the neonatal cardiovascular system of combined therapies remain to be further examined.

\section{AUTHOR CONTRIBUTIONS}

CJ and P-YC both made substantial contributions to the conception or design of the work, and literature review. CJ drafted the work. CJ and P-YC revised it critically for important intellectual content and approved it for publication. CJ and P-YC agreed to be accountable for all aspects of the work in ensuring that questions related to the accuracy or integrity of any part of the work are appropriately investigated and resolved.

15. Hoffman TM, Wernovsky G, Atz AM, Kulik TJ, Nelson DP, Chang AC, et al. Efficacy and safety of milrinone in preventing low cardiac output syndrome in infants and children after corrective surgery for congenital heart disease. Circulation (2003) 107:996-1002. doi: 10.1161/01.CIR.0000051365.81 920.28

16. Li J, Zhang G, Holtby H, Humpl T, Caldarone CA, Van Arsdell GS, et al. Adverse effects of dopamine on systemic hemodynamic status and oxygen transport in neonates after the Norwood procedure. J Am Coll Cardiol. (2006) 48:1859-64. doi: 10.1016/j.jacc.2006.07.038

17. McNamara PJ, Laique F, Muang-In S, Whyte HE. Milrinone improves oxygenation in neonates with severe persistent pulmonary hypertension of the newborn. J Crit Care (2006) 21:217-22. doi: 10.1016/j.jcrc.2006.01.001

18. Lechner E, Hofer A, Mair R, Moosbauer W, Sames- Dolzer E, Tulzer G. Arginine-vasopressin in neonates with vasodilatory shock after cardiopulmonary bypass. Eur J Pediatr. (2007) 166:1221-7. doi: 10.1007/s00431-006-0400-0

19. Tourneux P, Rakza T, Abazine A, Krim G, Storme L. Noradrenaline for management of septic shock refractory to fluid loading and dopamine or dobutamine in full-term newborn infants. Acta Paediatr. (2008) 97:177-80. doi: 10.1111/j.1651-2227.2007.00601.x

20. Tourneux P, Rakza T, Bouissou A, Krim G, Storme L. Pulmonary circulatory effects of norepinephrine in newborn infants with persistent pulmonary hypertension. J Pediatr. (2008) 153:345-9. doi: 10.1016/j.jpeds.2008.03.007

21. Bravo MC, López P, Cabañas F, Pérez-Rodríguez J, Pérez-Fernández E, Quero $\mathrm{J}$, et al. Acute effects of levosimendan on cerebral and systemic perfusion and oxygenation in newborns: an observational study. Neonatology (2011) 99:217-23. doi: 10.1159/000314955

22. De Carolis MP, Piastra M, Bersani I, Pardeo M, Stival E, Tempera A, et al. Levosimendan in two neonates with ischemic heart failure and pulmonary hypertension. Neonatology (2012) 101:201-5. doi: 10.1159/0003 29848

23. Ricci Z, Garisto C, Favia I, Vitale V, Di Chiara L, Cogo PE. Levosimendan infusion in newborns after corrective surgery for congenital heart disease: randomized controlled trial. Intensive Care Med. (2012) 38:1198-204. doi: 10.1007/s00134-012-2564-6

24. Alten JA, Borasino S, Toms R, Law MA, Moellinger A, Dabal RJ. Early initiation of arginine vasopressin infusion in neonates after complex cardiac surgery. Pediatr Crit Care Med. (2012) 13:300-4. doi: 10.1097/PCC.0b013e31822f1753

25. McNamara PJ, Shivananda SP, Sahni M, Freeman D, Taddio A. Pediatric pharmacology of milrinone in neonates with persistent pulmonary hypertension of the newborn and suboptimal response to inhaled nitric oxide. Crit Care Med. (2013) 14:74-84. doi: 10.1097/PCC.0b013e31824ea2cd

26. Mohamed A, Nasef N, Vibhuti Shah V, McNamara PJ. Vasopressin as a rescue therapy for refractory pulmonary hypertension in neonates: case series. Pediatr Crit Care (2014) 15:148-54. doi: 10.1097/PCC.0b013e31829f5fce 
27. Oualha M, Urien S, Spreux-Varoquaux O, Bordessoule A, D'Agostino I, Pouard P, et al. Pharmacokinetics, hemodynamic and metabolic effects of epinephrine to prevent post-operative low cardiac output syndrome in children. Crit Care (2014) 18:R23. doi: 10.1186/cc13707

28. Bianchi MO, Cheung PY, Phillipos E, Aranha-Netto A, Joynt C. The effect of milrinone on splanchnic and cerebral perfusion in infants with congenital heart disease prior to surgery: An observational study. Shock (2015) 44:11520. doi: 10.1097/SHK.0000000000000388

29. James AT, Corcoran JD, McNamara PJ, Franklin O, El-Khuffash AF. The effect of milrinone on right and left ventricular function when used as a rescue therapy for term infants with pulmonary hypertension. Cardiol Young (2016) 26:90-9. doi: 10.1017/S1047951114002698

30. Giaccone A, Zuppa AF, Sood B, Cohen MS, O’Byrne ML, Moorthy G, et al. Milrinone Pharmacokinetics and Pharmacodynamics in Neonates with Persistent Pulmonary Hypertension of the Newborn. Am J Perinatol. (2017)34:749-58. doi: 10.1055/s-0036-1597996

31. Walker BR, Haynes J Jr, Wang HL, Voelkel NF. Vasopressin-induced pulmonary vasodilation in rats. Am J Physiol. (1989) 257:H415-22.

32. Caspi J, Coles JG, Benson LN, Herman SL, Diaz RJ, Augustine J, et al. Age related response to epinephrine induced myocardial stress. A functional and ultrasound study. Circulation (1991) 84:III394-5.

33. Barrington KJ, Finer NN, Chan W. A blind, randomized comparison of the circulatory effects of dopamine and epinephrine infusions in the newborn piglet during normoxia and hypoxia. Crit Care Med. (1995) 23:740-8. doi: 10.1097/00003246-199504000-00024

34. Ferrera JJ, Dyess DL, Peeples GL, Christenberry DP, Roberts WS, Tacchi EJ, et al. Effects of dopamine and dobutamine on regional blood flow distribution in the neonatal piglet. Ann Surg. (1995) 221:531-42. doi: 10.1097/00000658-199505000-00011

35. Cheung PY, Barrington KJ, Bigam D. The hemodynamic effects of dobutamine infusion in the chronically instrumented newborn piglet. Crit Care Med. (1999) 27:558-64. doi: 10.1097/00003246-199903000-0 0036

36. Penny DJ, Sano T, Smolich JJ. Increased systemic oxygen consumption offsets improved oxygen delivery during dobutamine infusion in newborn lambs. Intensive Care Med. (2001) 27:1518-25. doi: 10.1007/s0013401 01044

37. Cheung PY, Barrington KJ. The effects of dopamine and epinephrine on hemodynamics and oxygen metabolism in hypoxic anesthetized piglets. Critical Care (2001) 5:158-68. doi: 10.1186/cc1016

38. Al-Salam Z, Johnson S, Abozaid S, Bigam D, Cheung PY. et al. The hemodynamic effects of dobutamine during reoxygenation after hypoxia: a dose-response study in newborn pigs. Shock (2007) 28:317-25. doi: 10.1097/shk.0b013e318048554a

39. Cheung PY, Abozaid S, Al-Salam Z, Johnson S, Li Y, Bigam D. Systemic and regional hemodynamic effects of high-dose epinephrine infusion in hypoxic piglets resuscitated with $100 \%$ oxygen. Shock (2007) 28:491-7. doi: 10.1097/shk.0b013e31804f77b8

40. Obaid L, Johnson ST, Emara M, Bigam DL, Cheung PY. Epinephrine versus dopamine to treat shock in hypoxic newborn pigs resuscitated with $100 \%$ oxygen: epinephrine versus dopamine in asphyxia. Shock (2008) 29:262-8. doi: 10.1097/shk.0b013e31811ff509

41. Joynt CA, Bigam D, Charrois G, Jewell LD, Korbutt G, et al. Doseresponse effects of milrinone on hemodynamics of newborn pigs with hypoxia-reoxygenation. Intensive Care Med. (2008) 34:1321-9. doi: 10.1007/s00134-008-1060-5

42. Joynt C, Bigam DL, Charrois G, Jewell LD, Korbutt G, Cheung PY. Milrinone, dobutamine or epinephrine use in asphyxiated newborn pigs resuscitated with 100\% oxygen. Intensive Care Med. (2010) 36:1058-66. doi: 10.1007/s00134-010-1820-x

43. Ichikawa Y, Yokoyama U, Iwamoto M, Oshikawa J, Okumura S, Sato $\mathrm{M}$, et al. Inhibition of phosphodiesterase type 3 dilates the rat ductus arteriosus without inducing intimal thickening. Circ J. (2012) 76:2456-64. doi: 10.1253/circj.CJ-12-0215

44. Esch J, Joynt C, Manouchehri N, Lee TF, Li YQ, Bigam D, et al. Differential hemodynamic effects of levosimendan in a porcine model of neonatal hypoxia-reoxygenation. Neonatology (2012) 101:192-200. doi: 10.1159/0003 29825
45. Cheung DC, Gill RS, Liu JQ, Manouchehri N, Sergi C, Bigam D, et al. Vasopressin improves systemic hemodynamics without compromising mesenteric perfusion in the resuscitation of asphyxiated newborn piglets: a dose-response study. Intensive Care Med. (2012) 38:491-8. doi: 10.1007/s00134-011-2437-4

46. Pelletier JS, LaBossiere J, Dicken B, Gill RS, Sergi C, Tahbaz N, et al. Low-dose vasopressin improves cardiac function in newborn piglets with acute hypoxia-reoxygenation. Shock (2013) 40:320-6. doi: 10.1097/SHK.0b013e3182a4284e

47. Drury PP, Booth LC, Bennet L, Davidson JO, Wibbens B, Gunn AJ. Dopamine infusion for postresuscitation blood pressure support after profound asphyxia in near-term fetal sheep. Exp Physiol. (2013) 98:699-709. doi: 10.1113/expphysiol.2012.069989

48. Manouchehri N, Bigam DL, Churchill T, Rayner D, Joynt C, Cheung PY. A comparison of combination dopamine and epinephrine treatment with highdose dopamine alone in asphyxiated newborn piglets after resuscitation. Pediatr Res. (2013) 73:435-42. doi: 10.1038/pr.2013.17

49. Eiby YA, Shrimpton NY, Wright IM, Lumbers ER, Colditz PB, Duncombe GJ, et al. Inotropes do not increas e cardiac output or cerebral blood flow in preterm piglets. Pediatr Res. (2016)80:870-9. doi: 10.1038/pr.2016.156

50. Eriksen VR, Rasmussen MB, Holst Hahn G, Greisen G. Dopamine therapy does not affect cerebral autoregulation during hypotension in newborn piglets. (2017) PLoS ONE 12:e0170738. doi: 10.1371/journal.pone.0170738

51. Mielgo VE, Valls-I-Soler A, Lopez-de-Heredia JM, Rabe H, Rey-Santano C. Hemodynamic and metabolic effects of a new pediatric dobutamine formulation in hypoxic newborn pigs. Pediatr Res. (2017)83:511-8. doi: 10.1038/pr.2016.257

52. Cornette L, Levene MI. Post resuscitative management of the asphyxiated term and preterm infant. Semin Neonatol. (2001) 6:271-82. doi: 10.1053/siny.2001.0055

53. Wessel D. Managing low cardiac output syndrome after congenital heart surgery. Crit Care Med. (2001) 29:S220-30. doi: 10.1097/00003246-200110001-00004

54. Wood T, Thoresen M. Physiological responses to hypothermia. Semin Fetal Neonatal Med. (2014) 20:87-96. doi: 10.1016/j.siny.2014.10.005

55. Bolli R, Jeroudi MO, Patel BS, DuBose CM, Lai EK, Roberts R, et al. Direct evidence that oxygen-derived free radicals contribute to postischemic myocardial dysfunction in the intact dog. Proc Natl Acad Sci USA. (1989) 86:4695-9. doi: 10.1073/pnas.86.12.4695

56. Brown JM, Terada LS, Grosso MA, Whitman GJ, Velasco SE, Patt A, et al. Hydrogen peroxide mediates reperfusion injury in the isolated rat heart. Mol Cell Biochem. (1988) 84:173-5. doi: 10.1007/BF00421052

57. Zweier JL, Kuppusamy P, Williams R, Rayburn BK, Smith D, Weisfeldt $\mathrm{ML}$, et al. Measurement and characterization of postischemic free radical generation in the isolated perfused heart. J Biol Chem (1989) 264:18890-5.

58. Liu P, Hock CE, Nagele R, Wong PY. Formation of nitric oxide, superoxide and peroxynitrite in myocardial ischemia-reprfusion injury in rats. Am J Physiol. (1997) 272:H2327-36.

59. Fernández-Checa JC, García-Ruiz C, Colell A, Morales A, Marí M, Miranda $\mathrm{M}$, et al. Oxidative stress: role of mitochondria and protection by glutathione. Biofactors (1998) 8:7-11.

60. Galinsky R, Lear CA, Yamaguchi K, Wassink G, Westgate JA, Bennet $\mathrm{L}$, et al. Cholinergic and $\beta$-adrenergic control of cardiovascular reflex responses to brief repeated asphyxia in term-equivalent fetal sheep. Am J Physiol Reg Integ Comp Physiol. (2016) 311:R949-56. doi: 10.1152/ajpregu. 00340.2016

61. Galinsky R, Jensen EC, Bennet L, Mitchell CJ, Gunn ER, Wassink G, et al. Sustained sympathetic nervous system support of arterial blood pressure during repeated brief umbilical cord occlusions in near-term fetal sheep. Am J Physiol Reg Integ Comp Physiol. (2014) 306:R787-95. doi: 10.1152/ajpregu.00001.2014

62. Evans N, Kluckow M, Currie A. Range of echocardiographic findings in term neonates with high oxygen requirements. Arch Dis Child Fetal Neonatal Ed (1998) 78:F105-11. doi: 10.1136/fn.78.2.F105

63. Lister GT, Walter TK, Versmold HT, allman PR, Rudolph AM. Oxygen delivery in lambs: cardiovascular and hematologic development. Am J Physiol. (1979) 237:H668-75. doi: 10.1152/ajpheart.1979.237. 6.H668 
64. Evans N. Which inotrope for which baby. Arc Dis Child Fetal Neonatal Ed. (2006) 91:F213-20.

65. Osborn D, Evans N, Kluckow M. Diagnosis and treatment of low systemic blood flow in preterm infants. Neoreviews (2004) 5:e109-21. doi: 10.1542/neo.5-3-e109

66. Ranjit MS. Cardiac abnormalities in birth asphyxia. Indian J Pediatr. (2000) 67:S26-9. doi: 10.1007/BF02760486

67. Fisher DJ. Acidaemia reduces cardiac output and left ventricular contractility in conscious lambs. J Dev Physiol. (1986) 8:23-31.

68. Greisen G. Autoregulation of cerebral blood flow in newborn babies. Ear Hum Dev. (2005) 81:423-8. doi: 10.1016/j.earlhumdev.2005. 03.005

69. Tsuji M, Saul PJ, du Plessis Adre, Eichenwald E, Sobh J, Crocker R, et al. Cerebral intravascular oxygenation correlates with mean arterial pressure in critically ill premature infants. Pediatrics (2000) 106:625-32. doi: $10.1542 /$ peds.106.4.625

70. Pryds O, Greisen G, Lou H, Fris-Hansen B. Vasoparalysis is associated with brain damage in asphyxiated term infants. J Pediatr. (1990) 117:119-25. doi: 10.1016/S0022-3476(05)72459-8

71. Bennet L, Booth L, Malpas SC, Quaedackers JS, Jensen E, Dean J, et al. Acute systemic complications in the preterm fetus after asphyxia: Role of cardiovascular and blood flow responses. Clin Exper Pharm Phys. (2006) 33:291-9. doi: 10.1111/j.1440-1681.2006.04364.x

72. Weindling AM, Kissack CM. Blood pressure and tissue oxygenation in the newborn baby at risk of brain damage. Biol Neonate (2001) 79:241-5. doi: 10.1159/000047099

73. Mace TP, Azar GJ, Lee RD, Choe EU, Burgess RS, Cork RC, et al. Effects of severe hypoxemia on mesenteric blood flow in neonatal piglets. J Surg Res. (1998) 80:287-94. doi: 10.1006/jsre.1998.5451

74. Alward CT, Hook JB, Helwrath TA, Mattson JC, Bailie MD. Effects of asphyxia on cardiac output and organ blood flow in the newborn piglet. Pediatr Res. (1978) 12:824-7. doi: 10.1203/00006450-19780800000003

75. Karna P, Senagore A, Chou C. Comparison of the effect of asphyxia, hypoxia and acidosis on intestinal blood flow and $\mathrm{O} 2$ uptake in newborn piglets. Pediatr Res. (1986) 20:929-32. doi: 10.1203/00006450-19861000000004

76. Haase E, Bigam DL, Nakonechny QB, Jewell LD, Korbutt G, Cheung PY, et al. Resuscitation with $100 \%$ oxygen causes intestinal glutathione oxidation and reoxygenation injury in asphyxiated newborn piglets. Ann Surg. (2004) 240:364-73. doi: 10.1097/01.sla.0000133348.58450.e4

77. Escourrou G, Renesme L, Zana E, Rideau A, Marcoux MO, Lopez E, et al. How to assess hemodynamic status in very preterm newborns in the first week of life? J Perinatol. (2017) 37:987-93. doi: 10.1038/jp.2017.57

78. Gebauer CM, Knuepfer M, Robel-Tillig E, Pulzer F, Vogtmann C. Hemodynamics among neonates with hypoxic-ischemic encephalopathy during whole-body hypothermia and passive rewarming. Pediatrics (2006)117:843e50. doi: 10.1542/peds.2004-1587

79. Espinoza A, Kerans V, Opdahl A, Skulstad H, Halvorsen PS, Bugge JF, et al. Effects of therapeutic hypothermia on left ventricular function assessed by ultrasound imaging. J Am Soc Echocardiogr. (2013) 26:1353e63. doi: 10.1016/j.echo.2013.06.021

80. Lewis ME, Al-Khalidi AH, Townend JN, Coote J, Bonser RS. The effects of hypothermia on human left ventricular contractile function during cardiac surgery. J Am Coll Cardiol. (2002) 39:102e8. doi: 10.1016/S07351097(01)01694-1

81. de Haan TR, Bijleveld YA, van der Lee JH, Groenendaal F, van den Broek MP, Rademaker CM, et al. Pharmacokinetics and pharmacodynamics of medication in asphyxiated newborns during controlled hypothermia. The PharmaCool multicenter study. BMC Pediatr. (2012) 12:45. doi: 10.1186/1471-2431-12-45

82. Zanelli S, Buck M, Fairchild K. Physiologic and pharmacologic considerations for hypothermia therapy in neonates. J Perinatol. (2011) 31:377-86. doi: 10.1038/jp.2010.146

83. Dempsey EM. What should we do about low blood pressure in preterm infants. Neonatology (2017) 111:402-7. doi: 10.1159/000460603

84. Childs EW, Udobi KF, Hunter FA. Hypothermia reduces microvascular permeability and reactive oxygen species expression after hemorrhagic shock. J Trauma (2005) 58:271e7. doi:10.1097/01.TA.0000119203.24601.7E

85. Kecskes Z, Healy G, Jensen A. Fluid restriction for term infants with hypoxicischaemic encephalopathy following perinatal asphyxia. Cochrane Database Syst Rev. (2005) 20:CD004337. doi: 10.1002/14651858.CD004337.pub2

86. Piazza AJ. Postasphyxial management of the newborn. Clin Perinatol. (1999) 26:749-65. doi: 10.1016/S0095-5108(18)30049-6

87. Seri I. Cardiovascular, renal, and endocrine actions of dopamine in neonates and children. J Pediatr. (1995) 126:333-44. doi: 10.1016/S0022-3476(95)70445-0

88. Seri I, Evans J. Controversies in the diagnosis and management of hypotension in the newborn infant. Curr Opin Pediatr. (2001) 12:116-23. doi: 10.1097/00008480-200104000-00005

89. Chatterjee K, De Marco T. Role of nonglycoside inotropic agents: indications, ethics and limitations. Med Clin N Am. (2003) 87:391-418. doi: 10.1016/S0025-7125(02)00185-2

90. Rios DR, Moffett BS, Kaiser JR. Trends in pharmacotherapy for neonatal hypotension. J Pediatr. (2014) 165:697-701. doi:10.1016/j.jpeds.2014.06.009

91. Subhedar NV. Treatment of hypotension in newborns. Semin Neonat. (2003) 8:413-23. doi: 10.1016/S1084-2756(03)00117-9

92. Engle WD, Leflore JL. Hypotension in the neonate. Neoreviews (2002) 3:e157-62. doi: 10.1542/neo.3-8-e157

93. Dempsey EM, Barrington KJ. Treating hypotension in the preterm infant: when and with what: a critical and systematic review. J Perinatol. (2007) 27:469-78. doi: 10.1038/sj.jp.7211774

94. Noori S, Freidlich P, Seri I. Developmentally regulated cardiovascular, renal and neuroendocrine effects of dopamine. Neoreviews (2003) 4:e283-8. doi: 10.1542/neo.4-10-e283

95. Seri I, Rudas G, Bors Z, Kanyicksa B, Tulassay T. Effects of low dose dopamine infusions in cardiovascular and renal functions, cerebral blood flow and plasma catecholamine levels in sick preterm neonates. Pediatr Res. (1993) 34:742-9. doi: 10.1203/00006450-199312000-00009

96. Noori S, Seri I. Neonatal blood pressure support: the use of inotropes, lusitropes, and other vasopressor agents. Clin Perinatol. (2012) 39:221-38. doi: 10.1016/j.clp.2011.12.010

97. Taketomo CK, Hodding JH, Kraus DM. Lexi-Comp's Pediatric Dosage Handbook. Hudson, OH: Lexi-Comp (2012) p 446-7.

98. Seri I. Management of hypotension and low systemic blood flow in the very low birth weight neonate during the first postnatal week. J Perinatol. (2006) 26(Suppl. 1):S8-13. doi: 10.1038/sj.jp.7211464

99. Padbury JF, Agata Y, Baylen BG, Ludlow JK, Polk DH, Habib DM, et al. Pharmacokinetics of dopamine in critically ill newborn infants. J Pediatr. (1990) 117:472-6. doi: 10.1016/S0022-3476(05)81101-1

100. Hunt R, Osborn D. Dopamine for prevention of morbidity and mortality in term newborn infants with suspected perinatal asphyxia. Cochrane Database Syst Rev. (2002) 3:CD003484. doi: 10.1002/14651858.CD003484

101. Liet JM, Boscher C, Gras-Leguen C, Gournay V, Debillon T, Rozé JC. Dopamine effects on pulmonary artery pressure in hypotensive preterm infants with patent ductus arteriosus. J Pediatr. (2002) 140:373-5. doi: $10.1067 / \mathrm{mpd} .2002 .123100$

102. Eriksen VR. Rational use of dopamine in hypotensive newborns: improving our understanding of the effect on cerebral autoregulation. Dan Med J. (2017)64:B5388.

103. Mahoney L, Shah G, Crook D, Rojas-Anaya H, Rabe H. A literature review of the pharmacokinetics and pharmacodynamics of dobutamine in neonates. Pediatr Cardiol. (2016) 37:14-23. doi: 10.1007/s00246-015-1263-9

104. Gupta S, Donn SM. Neonatal hypotension: dopamine or dobutamine? Semin Fetal Neonatal Med. (2014)19:54-9.

105. Martinez AM, Padbury JF, Thio S. Dobutamine pharmacokinetics and cardiovascular responses in critically ill neonates. Pediatrics (1992) 89:47-51.

106. Rieg AD, Schroth SC, Grottke O, Hein M, Ackermann D, Rossaint R, Schälte $\mathrm{G}$. Influence of temperature on the positive inotropic effect of levosimendan, dobutamine and milrinone. Eur J Anaesthesiol. (2009) 26:946-5. doi: 10.1097/EJA.0b013e328330e9a0

107. Basu SK, Kaiser JR, Guffey D, Minard CG, Guillet R, Gunn AJ,et al. Hypoglycaemia and hyperglycaemia are associated with unfavourable outcome in infants with hypoxic ischaemic encephalopathy: a post hoc analysis of the CoolCap Study. Arch Dis Child Fetal 
Neonatal Ed. (2016) 101:F149-55. doi: 10.1136/archdischild-2015-30 8733

108. Basu SK, Salemi JL, Gunn AJ, Kaiser JR, CoolCap Study Group. Hyperglycaemia in infants with hypoxic-ischaemic encephalopathy is associated with improved outcomes after therapeutic hypothermia: a post hoc analysis of the CoolCap Study. Arch Dis Child Fetal Neonatal Ed. (2017) 102:F299-306. doi: 10.1136/archdischild-2016-311385

109. Akita T, Joyner RW, Lu C, Kumar R, Hartzell HC. et al. Developmental changes in modulation of calcium currents of rabbit ventricular cells by phosphodiesterase inhibitors. Circulation (1994) 90:469-78. doi: 10.1161/01.CIR.90.1.469

110. Zuppa AF, Nicolson SC, Adamson PC, Wernovsky G, Mondick JT, Burnham $\mathrm{N}$, et al. Population pharmacokinetics of milrinone in neonates with hypoplastic left heart syndrome undergoing stage I reconstruction. Anesthes Anal. (2006)102:1062-9. doi: 10.1213/01.ane.0000198626.67391.34

111. Samiee-Zafarghandy S, Raman SR, van den Anker JN, McHutchison $\mathrm{K}$, Hornik CP, Clark RH, et al. Safety of milrinone use in neonatal intensive care units. Early Hum Dev. (2015) 91:31-5. doi: 10.1016/j.earlhumdev.2014.10.007

112. James AT, Beel C, Corcoran JD, McNamara PJ, Franklin O, El-Khuffash AF. Treatment of premature infants with pulmonary hypertension and right ventricular dysfunction with milrinone: a case series. J Perinatol. (2015) 35:268-73. doi: $10.1038 /$ jp.2014.208

113. Lakshminrusimha S, Konduri GG, Steinhorn RH. Considerations in the management of hypoxemic respiratory failure and persistent pulmonary hypertension in term and late preterm neonates. J Perinatol. (2016) 36:S12-9. doi: 10.1038/jp.2016.44

114. Bassler D, Choong K, McNamara P, Kirpalani H. Neonatal persistent pulmonary hypertension treated with milrinone: four case reports. Biol Neonate (2006) 89:1-5. doi: 10.1159/000088192

115. Vogt W, Läer S. Prevention for pediatric low cardiac output syndrome: results from the European survey EuLoCOS-Paed. Paediatr Anaesth. (2011) 21:1176-84. doi: 10.1111/j.1460-9592.2011.03683.x

116. Bassler D, Kreutzer K, McNamara P, Kirpalani H. et al. Milrinone for persistent pulmonary hypertension of the newborn. Cochrane Database Syst Rev. (2010)11:CD007802. doi: 10.1002/14651858.CD007802.pub2

117. Burkhardt BEU, Rücker G, Stiller B. Prophylactic milrinone for the prevention of low cardiac output syndrome and mortality in children undergoing surgery for congenital heart disease. Cochrane Database Syst Rev (2015) 3:CD009515. doi: 10.1002/14651858.CD009515.pub2

118. Sehgal A, Francis JV, Lewis AI. Use of milrinone in the management of haemodynamic instability following duct ligation. Eur J Pediatr. (2011)170:115-9. doi: 10.1007/s00431-010-1296-2

119. Jain A, Sahni M, El-Khuffash A, Khadawardi E, Sehgal A, McNamara PJ, et al. Use of targeted neonatal echocardiography to prevent postoperative cardiorespiratory instability after patent ductus arteriosus ligation. J Pediatr. (2012) 160:584-9. doi: 10.1016/j.jpeds.2011.09.027

120. Halliday M, Kavarana M, Ebeling M, Kiger J. Milrinone use for hemodynamic instability in patent ductus arteriosus ligation. J Matern Fetal Neonatal Med. (2017) 30:529-33. doi: 10.1080/14767058.2016.1177720

121. Seri I. Circulatory support of the sick preterm infant. Semin Neonatol.(2001) 6:85-95. doi: 10.1053/siny.2000.0034

122. Ryan JJ, HustonJ, KuttyS, Hatton ND, Bowman L, Tian L, et al. Right ventricular adaptation and failure in pulmonary arterial hypertension. Can J Cardiol. (2015) 31:391-406. doi: 10.1016/j.cjca.2015.01.023

123. Schwartz, S. Acute right ventricular failure. In: Redington AN, van Arsdell G, Anderson RH, editors. Congenital Diseases of the Right Heart. London: Springer-Verlag Publishers (2009). p. 213-8.

124. Oualha M, Tréluyer JM, Lesage F, de Saint Blanquat L, Dupic L, Hubert P, et al. Population pharmacokinetics and haemodynamic effects of norepinephrine in hypotensive critically ill children. Br J Clin Pharmacol. (2014) 78:886-97. doi: 10.1111/bcp.12412

125. Rizk MY, Lapointe A, Lefebvre F, Barrington KJ. Norepinephrine infusion improves haemodynamics in the preterm infants during septic shock. Acta Paediatr. (2018) 107:408-13. doi: 10.1111/apa.14112

126. Shivanna B, Rios D, Rossano J, Fernandes CJ, Pammi M. Vasopressin and its analogues for the treatment of refractory hypotension in neonates. Cochr Database Syst Rev. (2013) 3:CD009171. doi: 10.1002/14651858.CD009171.pub2

127. Treschan TA, Jurgen P. The vasopressin system: physiology and clinical strategies. Anesthesiology (2006) 105:599-612. doi: 10.1097/00000542-200609000-00026

128. Choong K, Kissoon N. Vasopressin in pediatric shock and cardiac arrest. Pediatr Crit Care Med. (2008) 9:372-9. doi: 10.1097/PCC.0b013e318172d7c8

129. Dyke PC II, Tobias JD. Vasopressin: applications in clinical practice. $J$ Intensive Care Med. (2004) 19:220-8. doi: 10.1177/0885066604265246

130. Meyer S, Gottschling S, Baghai A, Wurm D, Gortner L. Arginine-vasopressin in catecholamine-refractory septic vs. non-septic shock in extremely low birth weight infants with acute renal injury. Crit Care (2006) 10:R71-6. doi: 10.1186/cc4917

131. Beaulieu MJ. Vasopressin for the treatment of neonatal hypotension. Neonatal Netw. (2013) 32:120-4. doi: 10.1891/0730-0832.32.2.120

132. Schneider EG. Effect of vasopressin on adrenal steroidogenesis. Am J Physiol. (1988) 255(5Pt 2):R806-11.

133. Meyer S, Loffler G, Polcher T, Gottschling S, Gortner L. Vasopressin in catecholamine-resistant septic and cardiogenic shock in very-low-birthweight infants. Acta Paediatr. (2006) 95:1309-12. doi: 10.1080/08035250500538973

134. Bidegain M, Greenberg R, Simmons C, Dang C, Cotten CM, Smith PB. Vasopressin for refractory hypotension in extremely low birth weight infants. J Pediatr. (2010) 157:502-4. doi: 10.1016/j.jpeds.2010.04.038

135. Landry DW, Oliver JA. The pathogenesis of vasodilatory shock. N Engl J Med. (2001) 345:588-95. doi: 10.1056/NEJMra002709

136. Barrett LK, Singer M, Clapp LH. Vasopressin: mechanisms of action on the vasculature in health and in septic shock. Crit Care Med. (2007) 35:33-40. doi: 10.1097/01.CCM.0000251127.45385.CD

137. Tamaki T, Kiyomoto K, He H, Tomohiro A, Nishiyama A, Aki Y, et al. Vasodilation induced by vasopressin V2 receptor stimulation in afferent arterioles. Kidney Int. (1996) 49:722-9. doi: 10.1038/ki.1996.101

138. Evora PR, Pearson PJ, Schaff HV. Arginine vasopressin induces endothelium-dependent vasodilatation of the pulmonary artery. V1-receptor-mediated production of nitric oxide. Chest (1993) 103:1241-5.

139. Jin HK, Chen YF, Yang RH, McKenna TM, Jackson RM, Oparil S. Vasopressin lowers pulmonary artery pressure in hypoxic rats by releasing atrial natriuretic peptide. Am J Med Sci. (1989) 298:227-36.

140. Acker S, Kinsella JP, Abman S, Gien J. Vasopressin improves hemodynamic status in infants with congenital diaphragmatic hernia. J Pediatr. (2014) 165:53-8. doi: 10.1016/j.jpeds.2014.03.059

141. Masarwa R, Paret G, Perlman A, Reif S, Raccah B, Matok I. Role of vasopressin and terlipressin in refractory shock compared to conventional therapy in the neonatal and pediatric population: a systematic review, meta- analysis, and trial sequential analysis. Crit Care (2017) 21:1. doi: 10.1186/s13054-016-1589-6

142. Choong K, Bohn D, Fraser DD, Gaboury I, Hutchison JS, Joffe $\mathrm{AR}$, et al. Vasopressin in pediatric vasodilatory shock: a multicenter randomized controlled trial. Am J Respir Crit Care Med. (2009) 180:632-9. doi: $10.1164 / \mathrm{rccm} .200902-02210 \mathrm{C}$

143. Ikegami $H$, Funato $M$, Tamai $H$, Wada $H$, Nabetani $M$, Nishihara M. Low-dose vasopressin infusion therapy for refractory hypotension in ELBW infants. Pediatr Int. (2010) 52:368-73. doi: 10.1111/j.1442-200X.2009.02967.x

144. Lilleberg J, Nieminen MS, Akkila J, Heikkila L, Kuitunen A, Lehtonen L, et al. Effects of a new calcium sensitizer, levosimendan, on hemodynamics, coronary blood flow, and myocardial substrate utilization early after coronary artery bypass grafting. Eur Heart J. (1998) 19:660-8. doi: 10.1053/euhj.1997.0806

145. Givertz MM, Andreou C, Conrad CH, Colucci WS. Myocardial effects of levosimendan in humans with left ventricular dysfunction. Circulation (2007) 115:1218-24. doi: 10.1161/CIRCULATIONAHA.106.6 68640

146. Ajiro Y, Hagiwara N, Katsube Y, Sperelakis N, Kasanuki H. Levosimendan increases L-type $\mathrm{Ca}(2+)$ current via phosphodiesterase-3 inhibition in human cardiac myocytes. Eur J Pharmacol. (2002) 435:27-33. doi: 10.1016/S0014-2999(01)01569-2 
147. Yokoshikei H, Katsube Y, Sunagawa M, Sperelakis N. The novel calcium sensitizer levosimendan activates ATP-sensitive $\mathrm{K}+$ channel in rat ventricular cells. J Pharmacol Exp Ther. (1997) 283:375-83.

148. Vilaboa Pedrosa C, Martínez Roca C, Yáñez Gómez P, Martín Herranz MI. Experience with levosimendan in 32 paediatric patients. Pediatr Cardiol. (2015) 36:1038-41. doi: 10.1007/s00246-015-1117-5

149. Davies AO, Lefkowitz RJ. Regulation of beta-adrenergic receptors by steroid hormones. Annu Rev Physiol. (1984) 46:119-30.

150. Sasidharan P. Role of corticosteroids in neonatal blood pressure homeostasis. Clin Perinatol. (1998) 25:723-40. doi: 10.1016/S0095-5108(18)30108-8

151. Fernandez E, Schrader R, Watterberg K. Prevalence of low cortisol values in term and near-term infants with vasopressor-resistant hypotension. $J$ Perinatol. (2005) 25:114-8. doi: 10.1038/sj.jp.7211211

152. Chapados I, Chik C, Cheung PY. Plasma cortisol response to ACTH challenge in hypoxic newborn piglets resuscitated with $21 \%$ and 100\% oxygen. Shock (2010) 33:519-25. doi: 10.1097/SHK.0b013e3181c 99727

153. Pizarro CF, Troster EJ, Damiani D, Carcillo JA. Absolute and relative adrenal insufficiency in children with septic shock. Crit Care Med. (2005) 33:855-9. doi: 10.1097/01.CCM.0000159854.23324.84

154. Annane D, Bellissant E. Prognostic value of cortisol response in septic shock. JAMA (2000) 284:308-9. doi: 10.1001/jama.284.3.303

155. Fernandez EF, MontmanR, Watterberg KL. ACTH and cortisol response to critical illness in term and late preterm newborns. J Perinatol. (2008) 28:797-802. doi: 10.1038/jp.20 08.190

156. Aucott SW. Hypotension in the newborn: who needs hydrocortisone? J Perinatol. (2005) 25:77-8. doi: 10.1038/sj.jp.7211225

157. Chapados I, Lee TF, Chik CL, Cheung PY. Hydrocortisone administration increases pulmonary artery pressure in asphyxiated newborn piglets reoxygenated with 100\% oxygen. Eur J Pharmacol. (2011) 652:111-6. doi: 10.1016/j.ejphar.2010.10.089

158. Osborn SA, ParadisisM, Evans N. The effect of inotropes on morbidity and mortality in preterm infants with low systemic or organ blood flow. Cochr Database Syst Rev. (2007)24:CD005090. doi: 10.1002/14651858.CD005090.pub2

Conflict of Interest Statement: The authors declare that the research was conducted in the absence of any commercial or financial relationships that could be construed as a potential conflict of interest.

Copyright (c) 2018 Joynt and Cheung. This is an open-access article distributed under the terms of the Creative Commons Attribution License (CC BY). The use, distribution or reproduction in other forums is permitted, provided the original author(s) and the copyright owner(s) are credited and that the original publication in this journal is cited, in accordance with accepted academic practice. No use, distribution or reproduction is permitted which does not comply with these terms. 